\title{
A General and Efficient Synthesis of Two-Dimensional Monolayer Mesoporous Materials with Diverse Framework Compositions
}

Xuanyu Yang, ${ }^{\dagger}$ Yanyan $\mathrm{Li},{ }^{\dagger}$ Junhao Ma,${ }^{\dagger}$ Yidong Zou, ${ }^{\dagger}$ Xinran Zhou,,${ }^{\dagger}$ Xiaowei Cheng, ${ }^{\dagger}$ Fahad A. Alharthi, ${ }^{\ddagger}$ Abdulaziz A. Alghamdi, ${ }^{\ddagger}$ Yonghui Deng ${ }^{\dagger,},{ }^{*}$

† Department of Chemistry, State Key Laboratory of Molecular Engineering of Polymers, Shanghai Key Laboratory of Molecular Catalysis and Innovative Materials, and iChEM, Fudan University, Shanghai 200433, China.

‡ Department of Chemistry, College of Science, King Saud University, P.O. Box 2455, Riyadh 11451, Saudi Arabia.

§ State Key Lab of Transducer Technology, Shanghai Institute of Microsystem and Information Technology, Chinese Academy of Sciences, Shanghai 200050 China.

Synthesis of $3 D$ mesoporous $\mathrm{Ce}_{0.8} Z_{r_{0.2}} \mathrm{O}_{2}$. Typically, $\mathrm{PEO}_{117}-b-\mathrm{PS}_{130}(50 \mathrm{mg})$ was dissolved in THF $(2.0 \mathrm{~mL})$, and $91.7 \mathrm{mg} \mathrm{CeCl} \cdot 7 \mathrm{H}_{2} \mathrm{O}$ and $30 \mathrm{mg} \mathrm{Zr}(\mathrm{acac})_{4}$ were dissolved in $2.0 \mathrm{~mL}$ EtOH. The two solutions were then mixed together with further stirring for $2 \mathrm{~h}$. The obtained homogeneous solution was cast onto Petri dishes for evaporation of THF in a hood at $40{ }^{\circ} \mathrm{C}$ for $24 \mathrm{~h}$, followed by heating at $50{ }^{\circ} \mathrm{C}$ for $24 \mathrm{~h}$ and at $100{ }^{\circ} \mathrm{C}$ for another $24 \mathrm{~h}$ to form the inorganic-polymer composite. Finally, the composite was scraped and crushed into powders for calcination at $500{ }^{\circ} \mathrm{C}$ in air for 2 $\mathrm{h}$ to decompose the organic PEO- $b$-PS template, and the sample of 3D mesoporous $\mathrm{Ce}_{0.8} \mathrm{Zr}_{0.2} \mathrm{O}_{2}$ was obtained. 
Synthesis of 2D mesoporous carbon nanosheets. Briefly, $1 \mathrm{~g}$ of the resol precursor in THF solution (20 wt \%, containing $0.125 \mathrm{~g}$ phenol and $0.075 \mathrm{~g}$ formaldehyde) was added to $4 \mathrm{~mL}$ THF solution of PEO-b-PS (containing $0.05 \mathrm{~g}$ copolymer) with stirring to form a homogeneous solution. Then the solution was dropped into a tube containing $30 \mathrm{~g}$ of $\mathrm{KCl}$ powder, and followed by centrifugation at $2000 \mathrm{rpm}$ to make the solution containing inorganic-organic composite precursors uniformly coat on the surface of $\mathrm{KCl}$ microcrystals. The separated solids were kept in an oven at $40{ }^{\circ} \mathrm{C}$ to evaporate the solvent, and followed by heating at $50{ }^{\circ} \mathrm{C}$ for $24 \mathrm{~h}$ and at $100{ }^{\circ} \mathrm{C}$ for another $24 \mathrm{~h}$ to form the composite on $\mathrm{KCl}$ surface, which was then calcined in $\mathrm{N}_{2}$ at $500{ }^{\circ} \mathrm{C}$ for $2 \mathrm{~h}$. Finally, the product of $2 \mathrm{D}$ mesoporous carbon nanosheets was obtained by dissolving $\mathrm{KCl}$ with amount of deionized water.

Synthesis of $2 \mathrm{D}$ mesoporous $\mathrm{SiO}_{2}$ nanosheets. Briefly, $50 \mathrm{mg}$ of $\mathrm{PEO}_{117}-b-\mathrm{PS}_{130}$ was dissolved in $4.0 \mathrm{~mL}$ THF, and then $0.5 \mathrm{~g}$ TEOS and $0.15 \mathrm{~g} 0.1 \mathrm{M} \mathrm{HCl}$ was added to form the homogenous solution. Then the solution was dropped into a tube containing $30 \mathrm{~g}$ of $\mathrm{KCl}$ powder, and followed by centrifugation at $2000 \mathrm{rpm}$ to make the solution containing inorganic-organic composite precursors uniformly coat on the surface of $\mathrm{KCl}$ microcrystals. The separated solids were kept in an oven at $40{ }^{\circ} \mathrm{C}$ to evaporate the solvent, and followed by heating at $50{ }^{\circ} \mathrm{C}$ for $24 \mathrm{~h}$ and at $100{ }^{\circ} \mathrm{C}$ for another $24 \mathrm{~h}$ to form the composite on $\mathrm{KCl}$ surface, which was then calcined in air at $500{ }^{\circ} \mathrm{C}$ for 2 h. Finally, the product of $2 \mathrm{D}$ mesoporous $\mathrm{SiO}_{2}$ nanosheets was obtained by dissolving $\mathrm{KCl}$ with amount of deionized water. 
Synthesis of $2 D$ mesoporous $\boldsymbol{W O}_{3}$ nanosheets. Briefly, $50 \mathrm{mg}$ of $\mathrm{PEO}_{117}-b$ - $\mathrm{PS}_{130}$ was dissolved in $4.0 \mathrm{~mL}$ THF, and then $150 \mathrm{mg} \mathrm{WCl}_{6}$ and $0.15 \mathrm{~mL}$ nitric acid was added under vigorous stirring to form the homogenous solution. The following procedures were the same with that for $2 \mathrm{D}$ mesoporous $\mathrm{Ce}_{0.8} \mathrm{Zr}_{0.2} \mathrm{O}_{2}$ nanosheets.

Synthesis of $2 \mathrm{D}$ mesoporous $\mathrm{ZrO}_{2}$ nanosheets. Briefly, $50 \mathrm{mg}$ of $\mathrm{PEO}_{117}-b$ - $\mathrm{PS}_{130}$ was dissolved in $4.0 \mathrm{~mL} \mathrm{THF}$, and then $150 \mathrm{mg} \mathrm{Zr}(\mathrm{acac})_{4}$ was added to form the homogenous solution. After $1 \mathrm{~h}, 0.15 \mathrm{~mL}$ nitric acid was added under vigorous stirring. The following procedures were the same with that for $2 \mathrm{D}$ mesoporous $\mathrm{Ce}_{0.8} \mathrm{Zr}_{0.2} \mathrm{O}_{2}$ nanosheets.

Synthesis of $2 \mathrm{D}$ mesoporous $\mathrm{TiO}_{2}$ nanosheets. Briefly, $50 \mathrm{mg}$ of $\mathrm{PEO}_{117}-b-\mathrm{PS}_{130}$ was dissolved in $4.0 \mathrm{~mL}$ THF, and then $0.15 \mathrm{~mL}$ hydrochloric acid $(0.1 \mathrm{M})$ and $150 \mathrm{mg}$ TBOT were successively added to form the homogenous solution. The following procedures were similar with that for $2 \mathrm{D}$ mesoporous $\mathrm{Ce}_{0.8} \mathrm{Zr}_{0.2} \mathrm{O}_{2}$ nanosheets. 

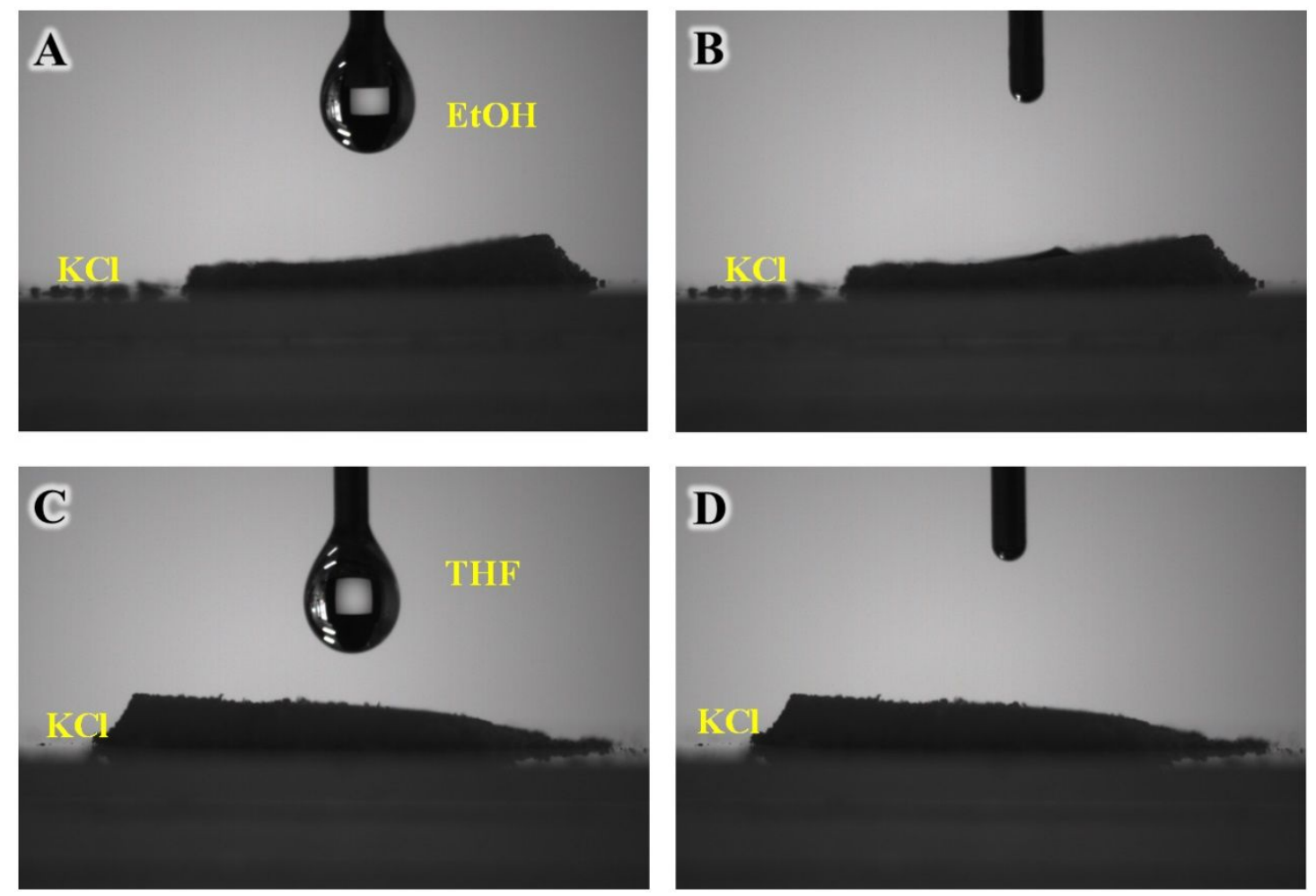

Figure S1. Static contact angles on $\mathrm{KCl}$ crystals (A) before dropping $\mathrm{EtOH}$ on $\mathrm{KCl}$; (B) after dropping $\mathrm{EtOH}$ on $\mathrm{KCl}$; (C) before dropping $\mathrm{THF}$ on $\mathrm{KCl}$; (D) after dropping $\mathrm{THF}$ on $\mathrm{KCl}$. It shows that their contact angles are $\sim 0^{\circ}$, indicating the hydrophilic surface of $\mathrm{KCl}$ crystals.
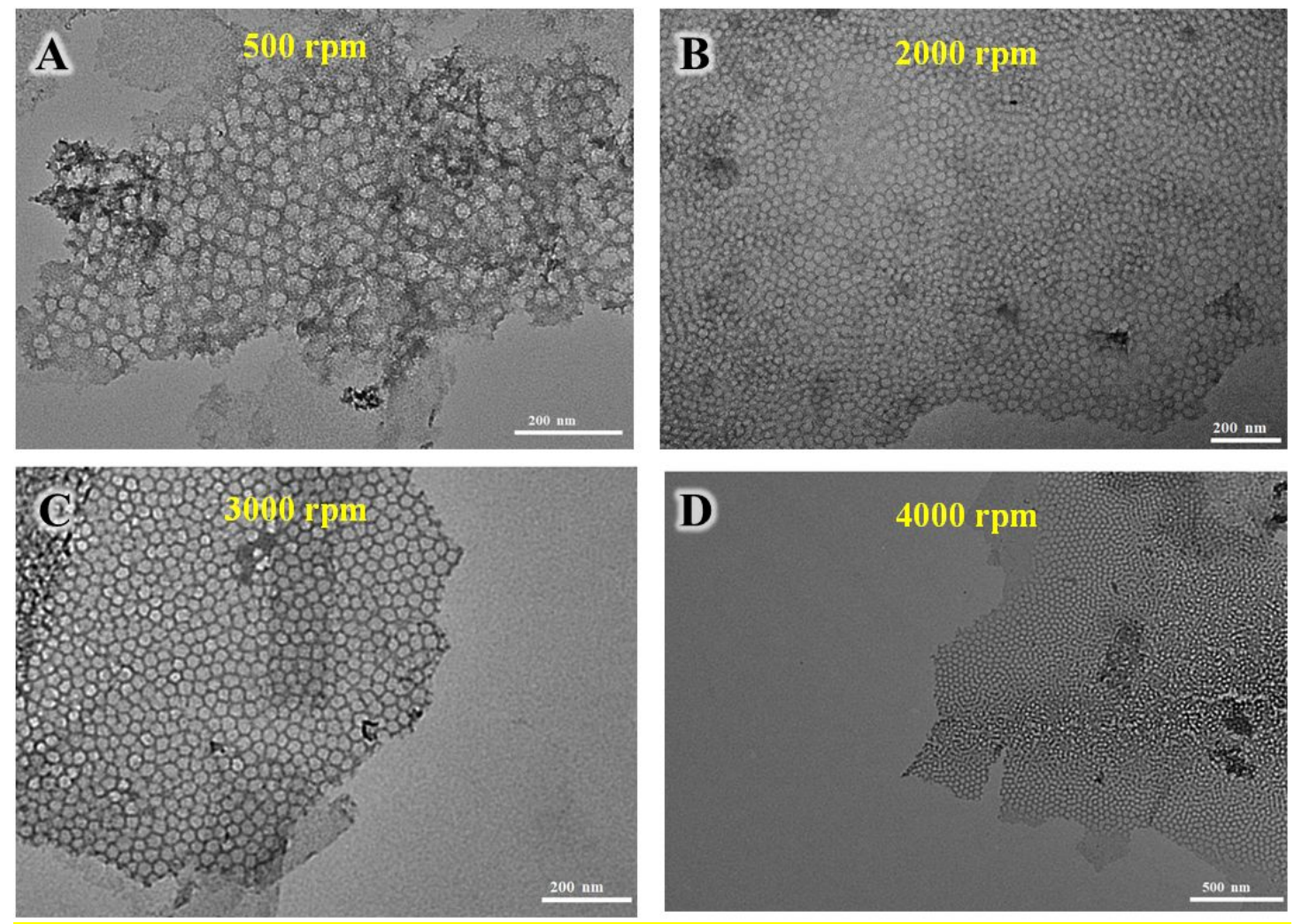
Figure S2. The obtained 2D mesoporous $\mathrm{ZrO}_{2}$ nanosheets synthesized with the speed of centrifugation with A) 500, B) 2000, C) 3000 and D) $4000 \mathrm{rpm}$.
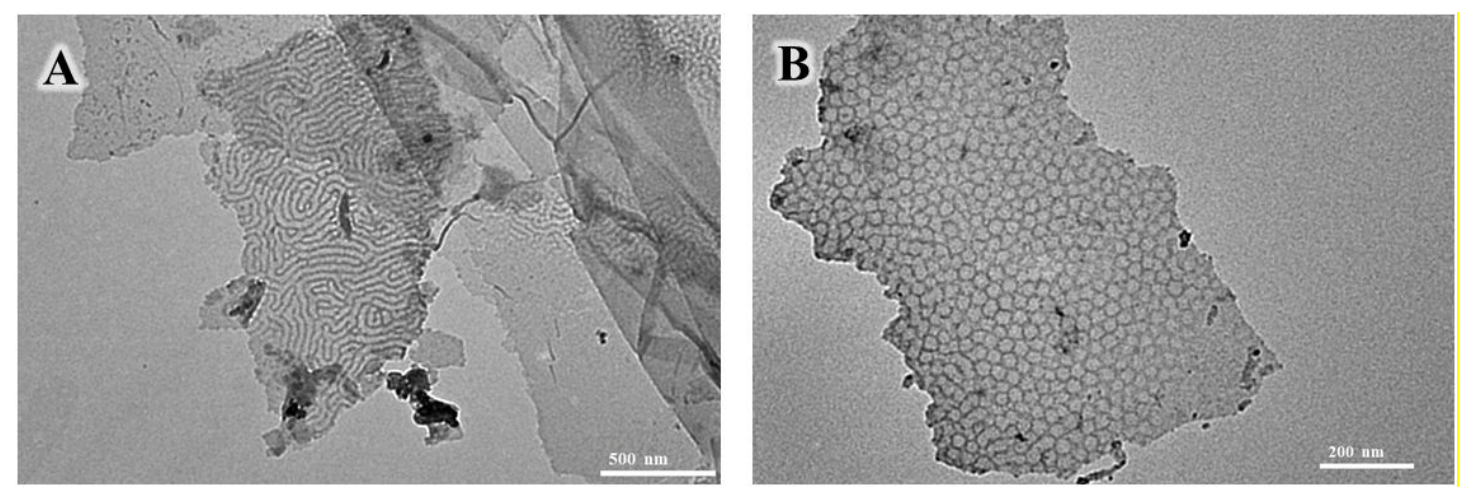

Figure S3. The obtained 2D mesoporous $\mathrm{ZrO}_{2}$ nanosheets synthesized with the solution gel of A) $8 \mathrm{~mL}$ THF solution contained $50 \mathrm{mg}$ PEO- $b$-PS and $150 \mathrm{mg}$ $\mathrm{Zr}(\mathrm{acac})_{4}$, B) $2 \mathrm{~mL}$ THF solution contained $50 \mathrm{mg}$ PEO- $b$-PS and $150 \mathrm{mg} \mathrm{Zr}(\mathrm{acac})_{4}$.

When $8 \mathrm{~mL}$ of THF solution contained $50 \mathrm{mg}$ PEO- $b$-PS and $150 \mathrm{mg} \mathrm{Zr}(\mathrm{acac})_{4}$ is used, the curved columnar micelle is formed due to the low concentration of the surfactant and inorganic precursor. Therefore, only small amount of the composite micelles that can be attached on the $\mathrm{KCl}$ surface, as a result, the curved columnar micelle forms in the solvent evaporation process. When $2 \mathrm{~mL}$ of THF solution contained $50 \mathrm{mg}$ PEO- $b$-PS and $150 \mathrm{mg} \mathrm{Zr(acac})_{4}$ is used, as shown in Figure 2, the monolayer spherical composite micelles forms, therefore, the concentration of the synthesis gel can greatly affect the meso-structure of the obtained materials.
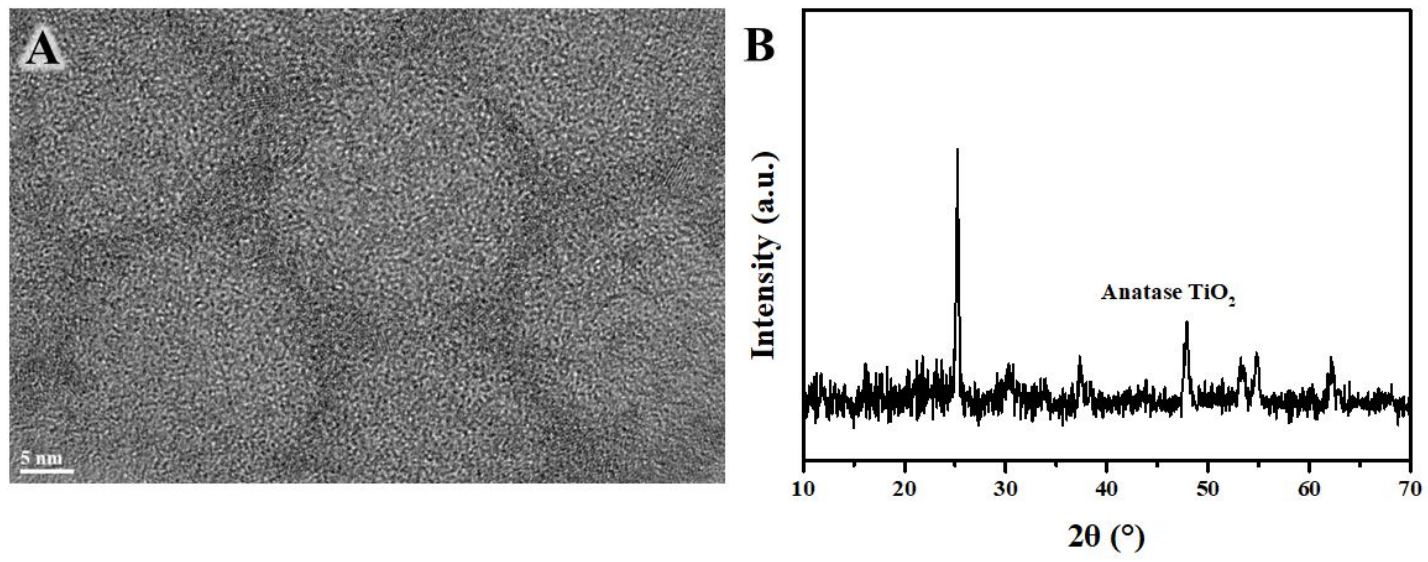

Figure S4. (A) HRTEM image of the 2D mesoporous $\mathrm{TiO}_{2}$ nanosheets; (B) XRD patterns of $2 \mathrm{D}$ mesoporous $\mathrm{TiO}_{2}$ nanosheets. 

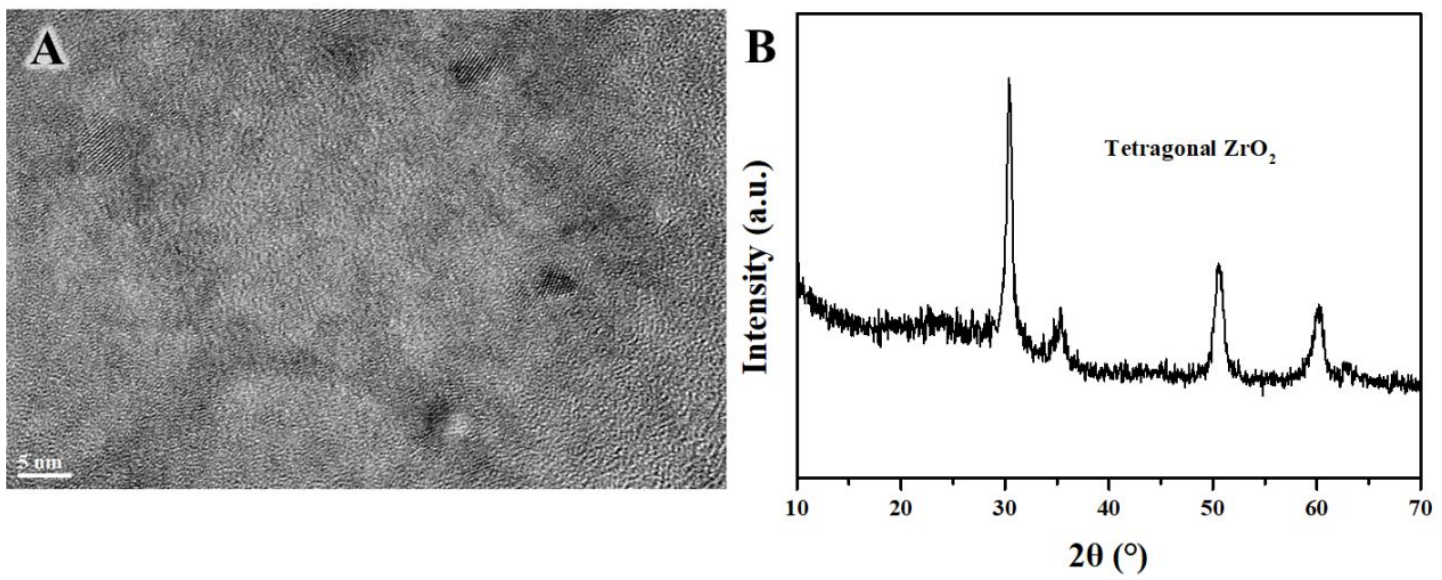

Figure S5. (A) HRTEM image of the 2D mesoporous $\mathrm{ZrO}_{2}$ nanosheets; (B) XRD patterns of 2D mesoporous $\mathrm{ZrO}_{2}$ nanosheets.
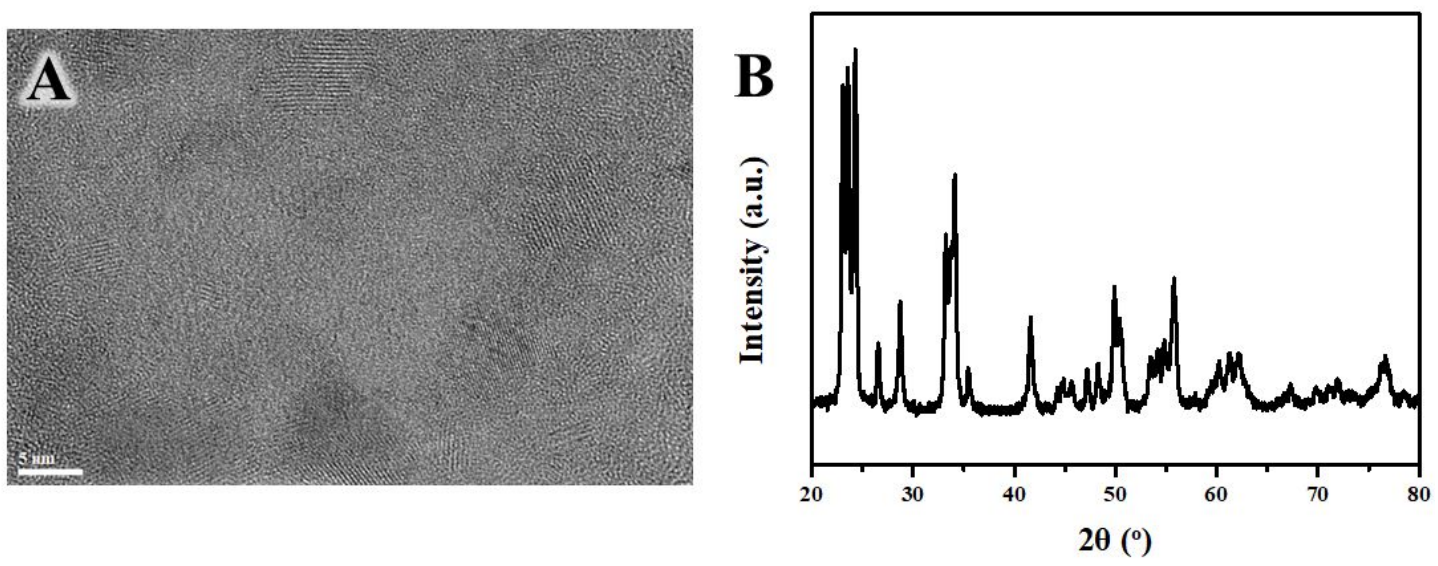

Figure S6. (A) HRTEM image of the 2D mesoporous $\mathrm{WO}_{3}$ nanosheets; (B) XRD patterns of $2 \mathrm{D}$ mesoporous $\mathrm{WO}_{3}$ nanosheets. 


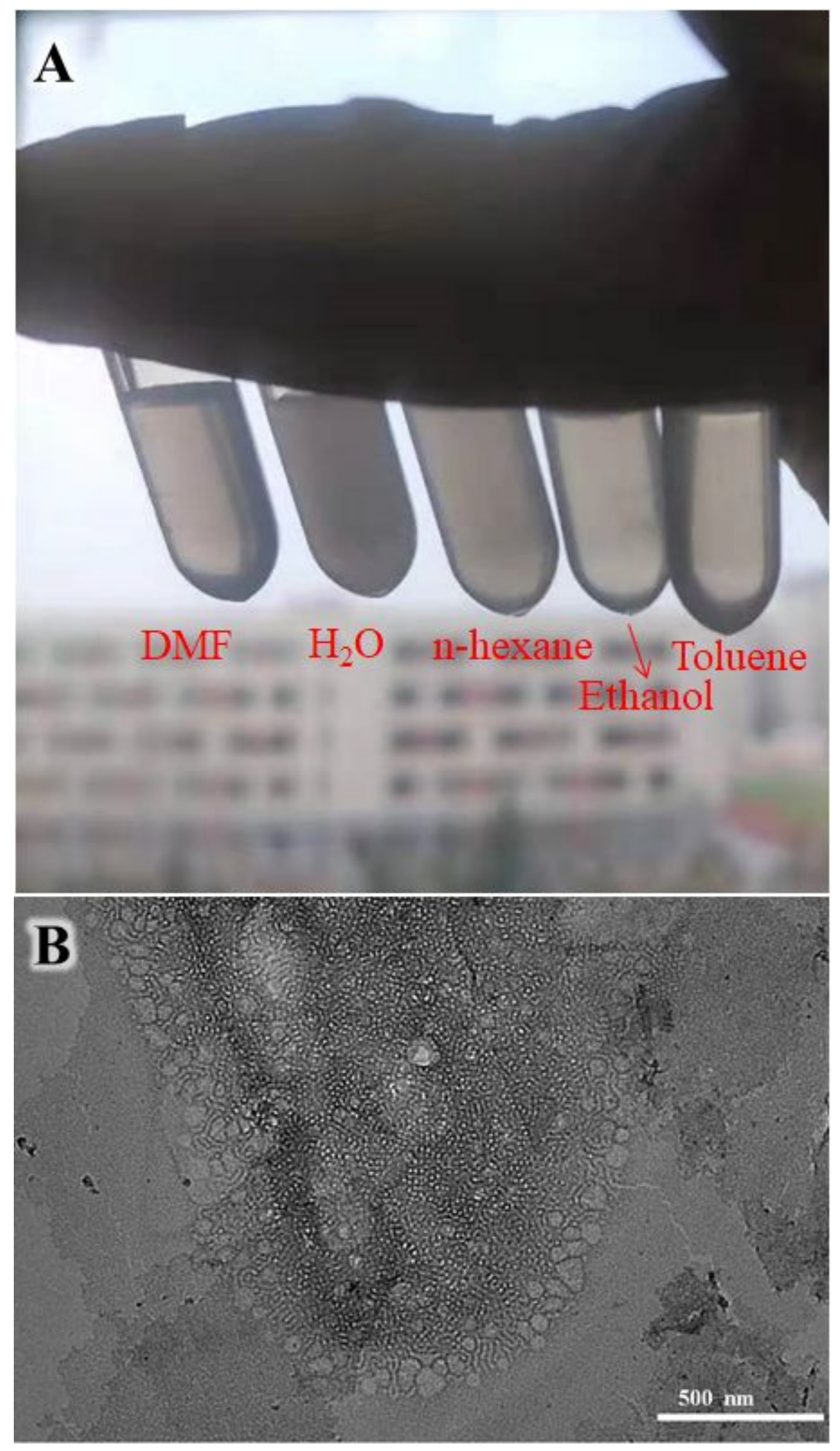

Figure S7. A) The optical images of 2D mesoporous $\mathrm{ZrO}_{2}$ nanosheets dispersed in $\mathrm{N}, \mathrm{N}$-dimethyllformamide, $\mathrm{H}_{2} \mathrm{O}$, n-hexane, ethanol, and toluene. B) 2D mesoporous $\mathrm{ZrO}_{2}$ nanosheets template by $\mathrm{F} 127$. 

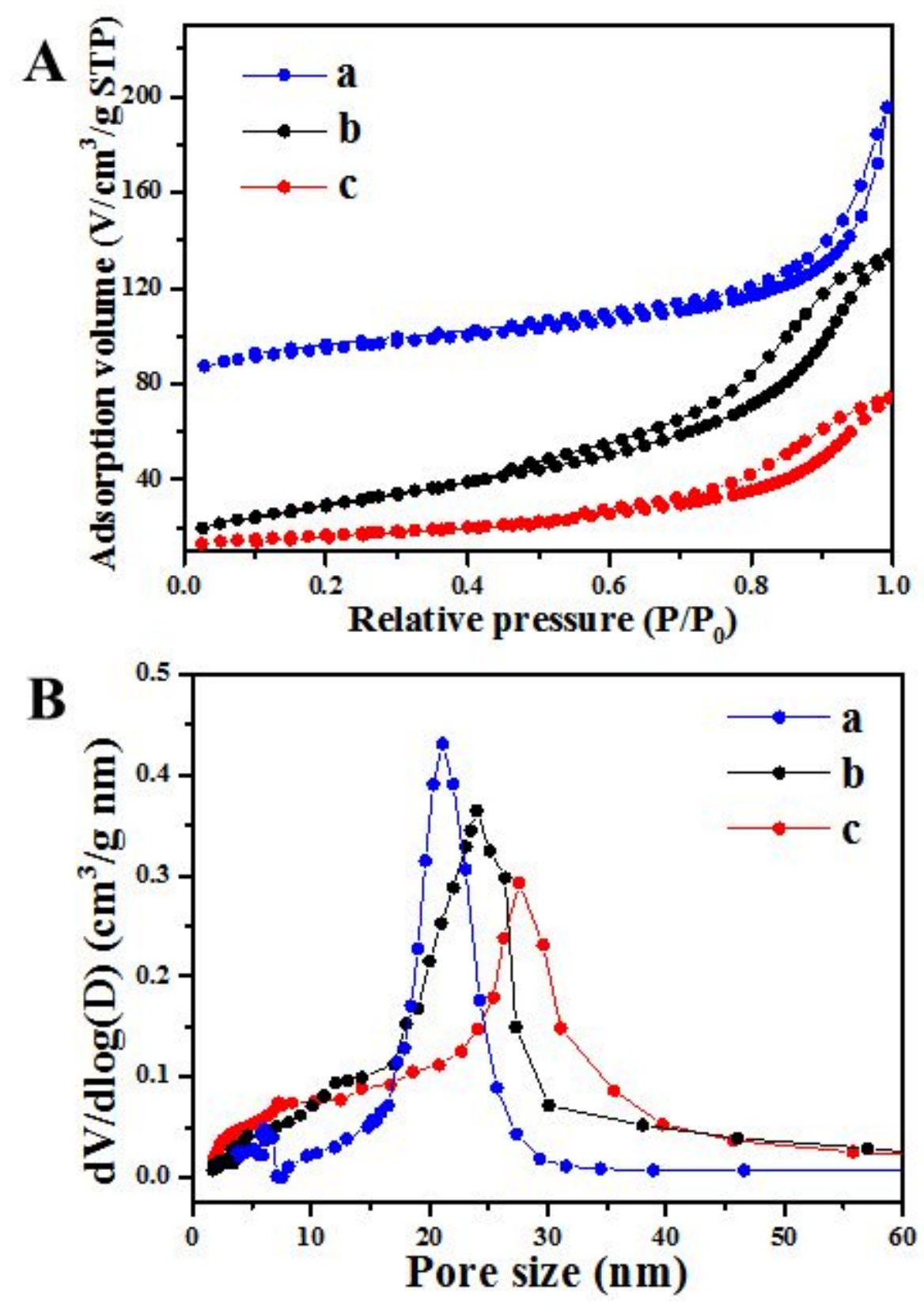

Figure S8 (A) $\mathrm{N}_{2}$ sorption isotherms and (B) pore size distribution curves of the $2 \mathrm{D}$ mesoporous $\mathrm{Ce}_{0.8} \mathrm{Zr}_{0.2} \mathrm{O}_{2}$ nanosheets. (a, $\mathrm{Ce}_{0.8} \mathrm{Zr}_{0.2} \mathrm{O}_{2}-\mathrm{PEO}_{47}-b$ - $\mathrm{PS}_{169}$ nanosheets; $\mathrm{b}$, $\mathrm{Ce}_{0.8} \mathrm{Zr}_{0.2} \mathrm{O}_{2}-\mathrm{PEO}_{117}-b$ - $\mathrm{PS}_{182}$ nanosheets; c, $\mathrm{Ce}_{0.8} \mathrm{Zr}_{0.2} \mathrm{O}_{2}-\mathrm{PEO}_{117}-b-\mathrm{PS}_{220}$ nanosheets. The sorption isotherms are vertically offset by $60,0,-60 \mathrm{~cm}^{3} \cdot \mathrm{g}^{-1}$ from (a) to (c), respectively, for clarity. STP: standard temperature and pressure. 

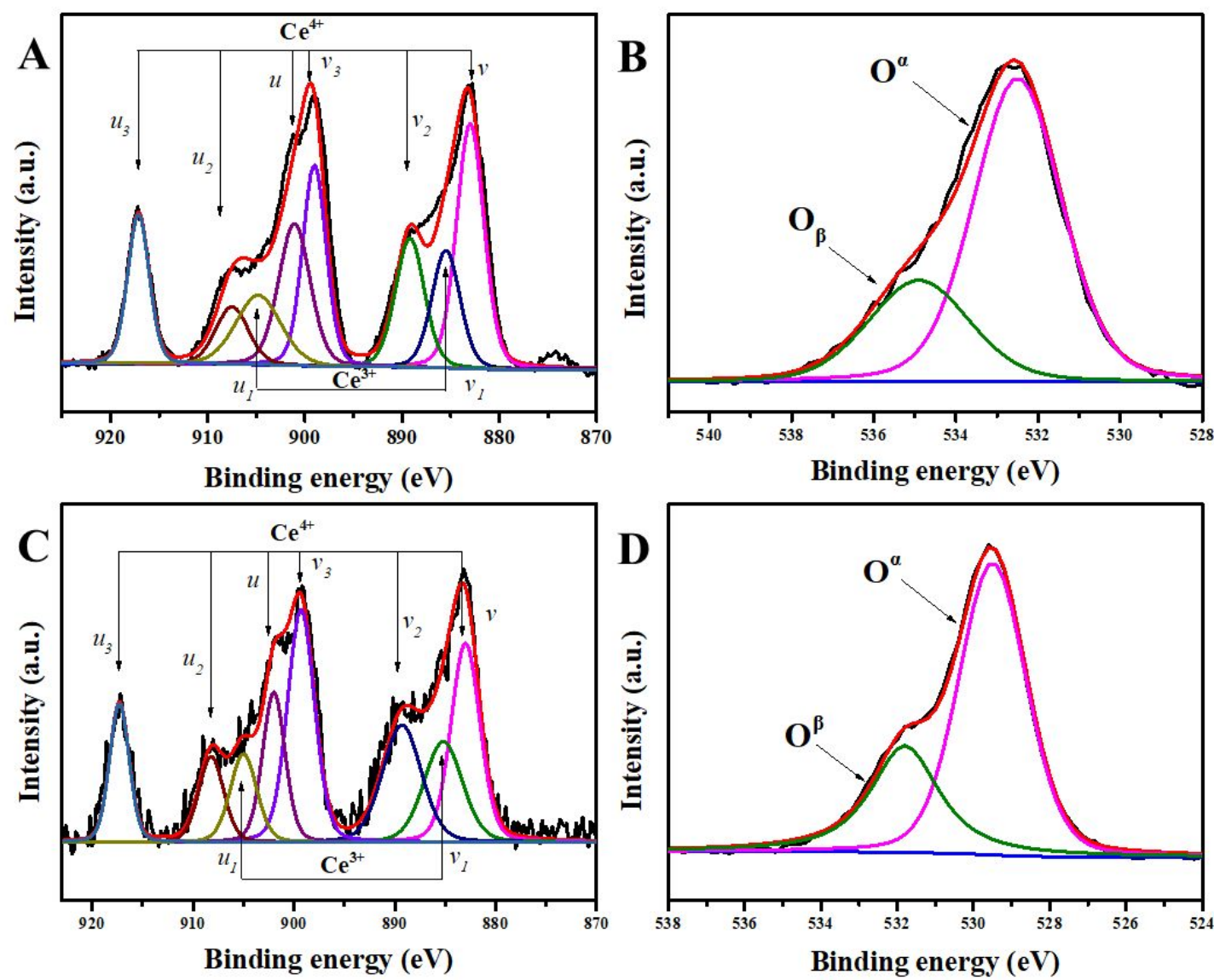

Figure S9. (A) $\mathrm{Ce} 3 d$ and (B) $\mathrm{O} 1 s$ XPS spectra of $2 \mathrm{D}$ mesoporous $\mathrm{Ce}_{0.8} \mathrm{Zr}_{0.2} \mathrm{O}_{2}$ nanosheet; (C) Ce $3 d$ and (D) O $1 s$ XPS spectra of $3 \mathrm{D}$ mesoporous $\mathrm{Ce}_{0.8} \mathrm{Zr}_{0.2} \mathrm{O}_{2}$.
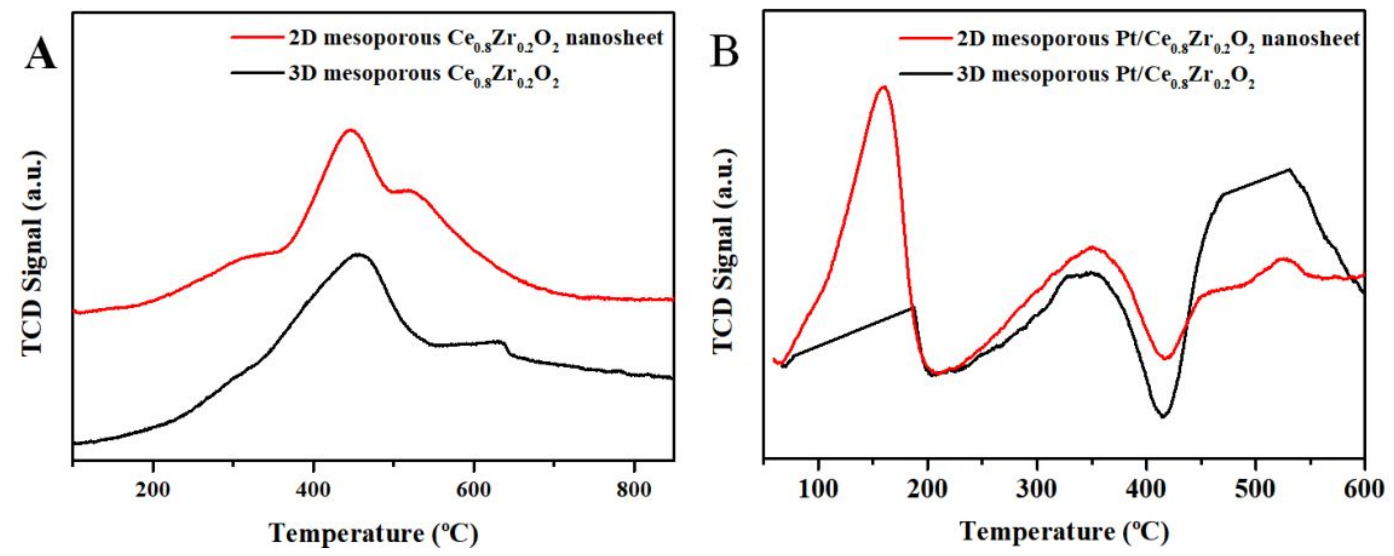

Figure S10. (A) $\mathrm{H}_{2}$-TPR profiles of the 2D mesoporous $\mathrm{Ce}_{0.8} \mathrm{Zr}_{0.2} \mathrm{O}_{2}$ nanosheets and 3D mesoporous $\mathrm{Ce}_{0.8} \mathrm{Zr}_{0.2} \mathrm{O}_{2}$; (B) $\mathrm{H}_{2}$-TPR profiles of the $2 \mathrm{D}$ mesoporous $\mathrm{Pt} / \mathrm{Ce}_{0.8} \mathrm{Zr}_{0.2} \mathrm{O}_{2}$ nanosheets and 3D mesoporous $\mathrm{Pt} / \mathrm{Ce}_{0.8} \mathrm{Zr}_{0.2} \mathrm{O}_{2}$.

To gain more insight about the mechanism for the superior catalytic performance of $2 \mathrm{D}$ mesoporous $\mathrm{Pt} / \mathrm{Ce}_{0.8} \mathrm{Zr}_{0.2} \mathrm{O}_{2}$ nanosheet, $\mathrm{H}_{2}$-temperature-programmed reduction 
(TPR) experiments were carried out to evaluate the reducibility of the obtained catalysts. The $\mathrm{H}_{2}$-TPR curves of original 2D mesoporous $\mathrm{Ce}_{0.8} \mathrm{Zr}_{0.2} \mathrm{O}_{2}$ nanosheets show two obvious reduction peaks centered around 450 and $650{ }^{\circ} \mathrm{C}$, respectively, which can be attributed to the surface and bulk reduction of $\mathrm{Ce}^{4+}$, respectively. ${ }^{[1]} \mathrm{In}$ addition, the $\mathrm{H}_{2}$ consumption of $2 \mathrm{D}$ mesoporous nanosheets $(0.61 \mathrm{mmol} / \mathrm{g})$ is much higher than the 3D mesoporous $\mathrm{Ce}_{0.8} \mathrm{Zr}_{0.2} \mathrm{O}_{2}(0.52 \mathrm{mmol} / \mathrm{g})$, indicating that the $2 \mathrm{D}$ nanosheets possess the much more surface reduction sites. After loading $\mathrm{Pt}$ nanoparticles, two corresponding reduction peaks of the obtained catalysts were found to shift to much lower temperature regions around 350 and $600{ }^{\circ} \mathrm{C}$, respectively, indicative of dramatically enhanced reduction ability. This phenomenon is mainly due to the hydrogen spillover from the dissociated $\mathrm{H}_{2}$ on Pt surfaces to the vicinity of metal oxide support, ${ }^{[2]}$ which significantly promoted the reducibility of the catalyst at low temperatures. ${ }^{[3]}$ 

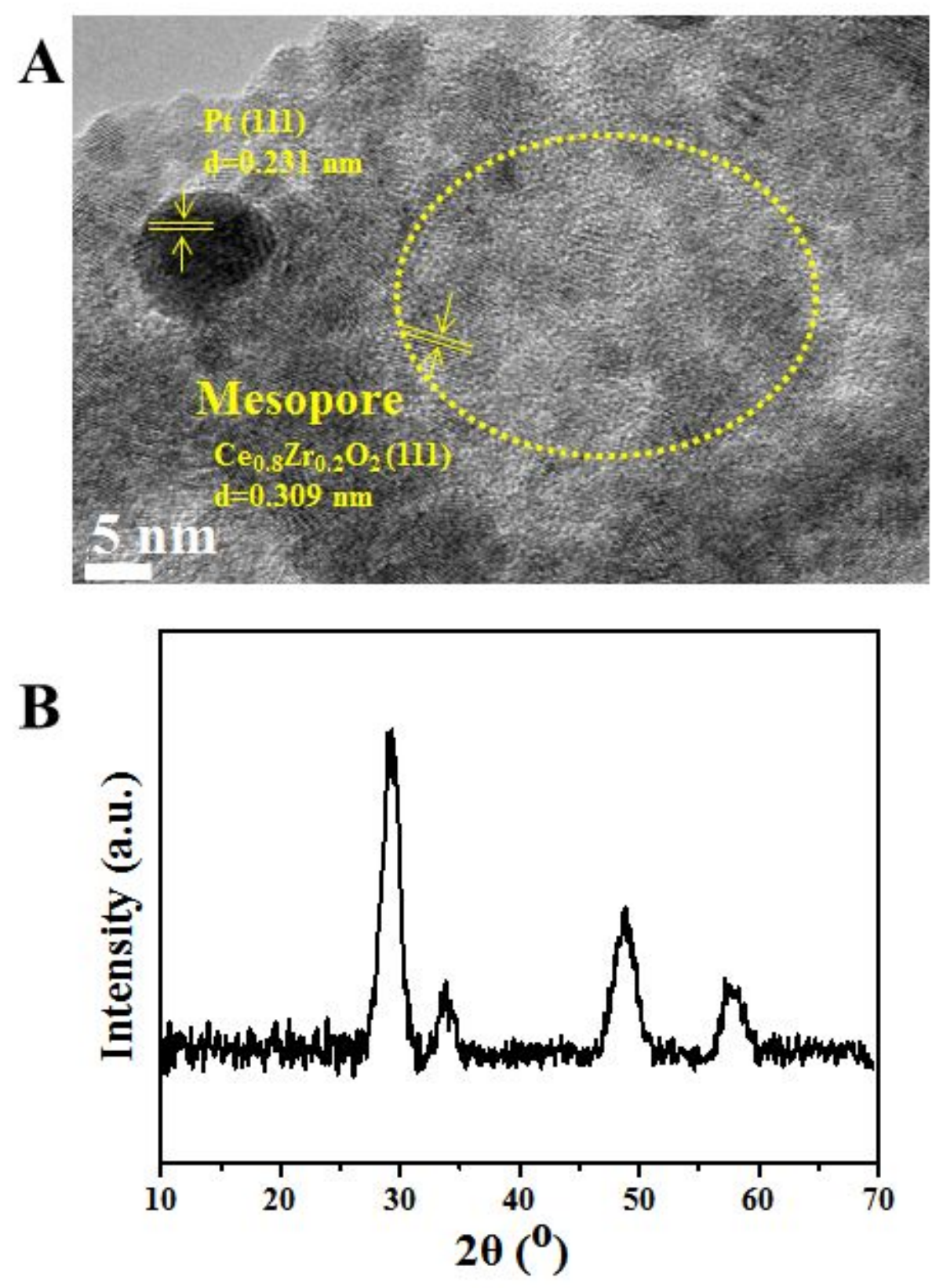

Figure S11. (A) HRTEM of $2 \mathrm{D}$ mesoporous $\mathrm{Pt} / \mathrm{Ce}_{0.8} \mathrm{Zr}_{0.2} \mathrm{O}_{2}$ nanosheets; (B) XRD patterns of $2 \mathrm{D}$ mesoporous $\mathrm{Pt} / \mathrm{Ce}_{0.8} \mathrm{Zr}_{0.2} \mathrm{O}_{2}$ nanosheets. 

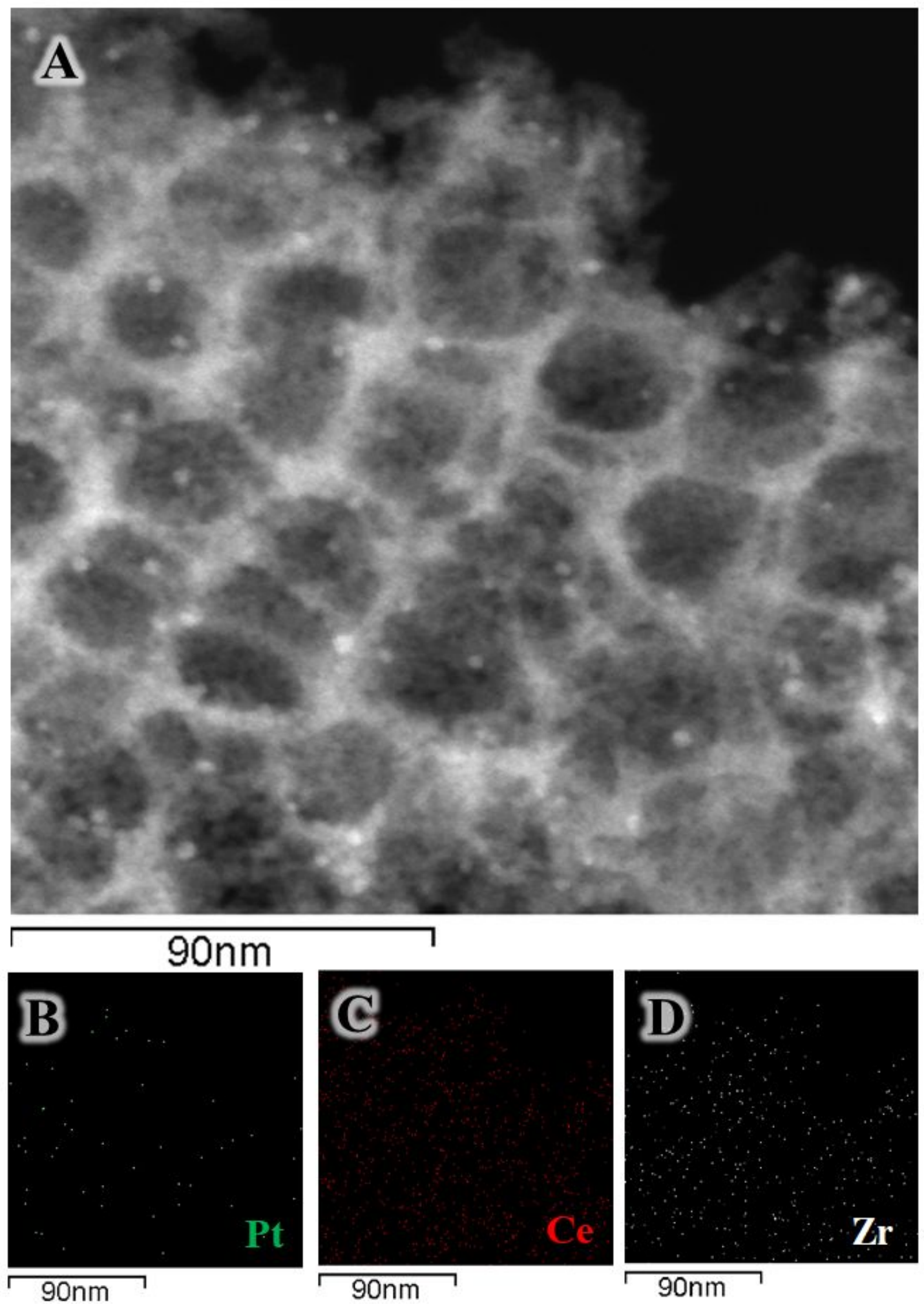

Figure S12. (A) HAADF-STEM image and energy-dispersive $\mathrm{X}$-ray element mapping of $\mathrm{Pt}(\mathrm{B}), \mathrm{Ce}(\mathrm{C})$ and $\mathrm{Zr}(\mathrm{D})$ elements in the mesoporous $\mathrm{Pt} / \mathrm{Ce}_{0.8} \mathrm{Zr}_{0.2} \mathrm{O}_{2}$. 

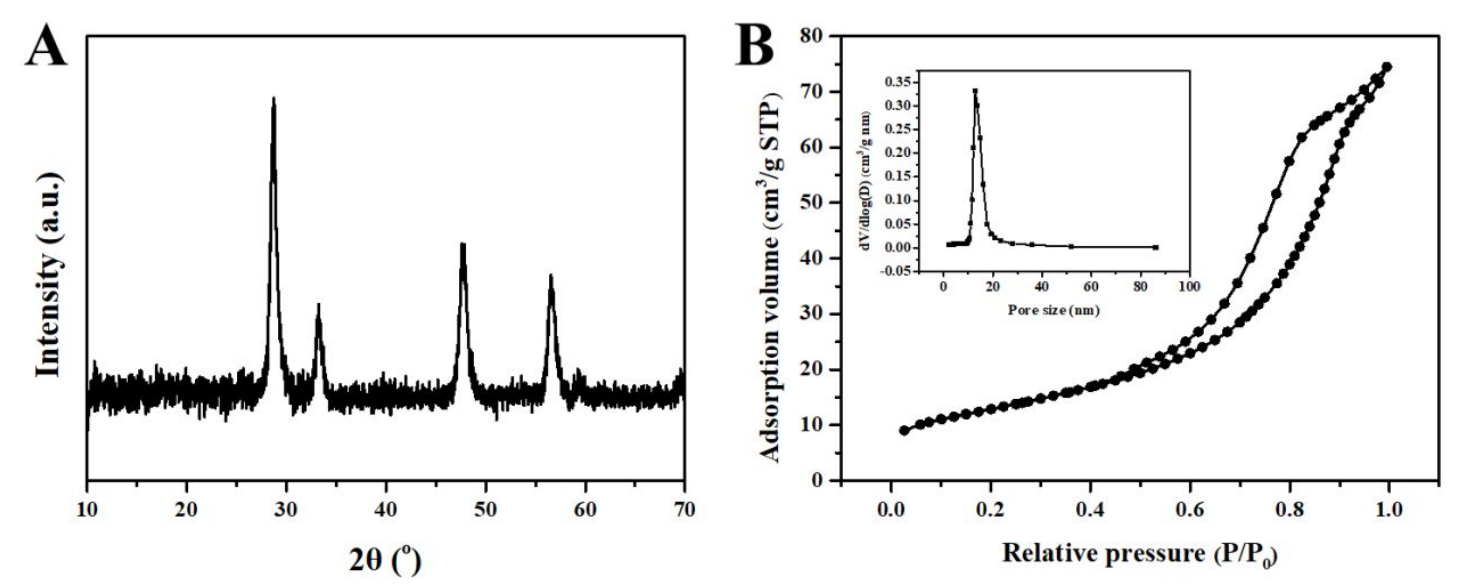

Figure S13. (A) WAXRD pattern of samples; (B) Nitrogen adsorption-desorption isotherms of samples, the inset is the pore size distribution of mesoporous $\mathrm{Pt} / \mathrm{Ce}_{0.8} \mathrm{Zr}_{0.2} \mathrm{O}_{2}$.
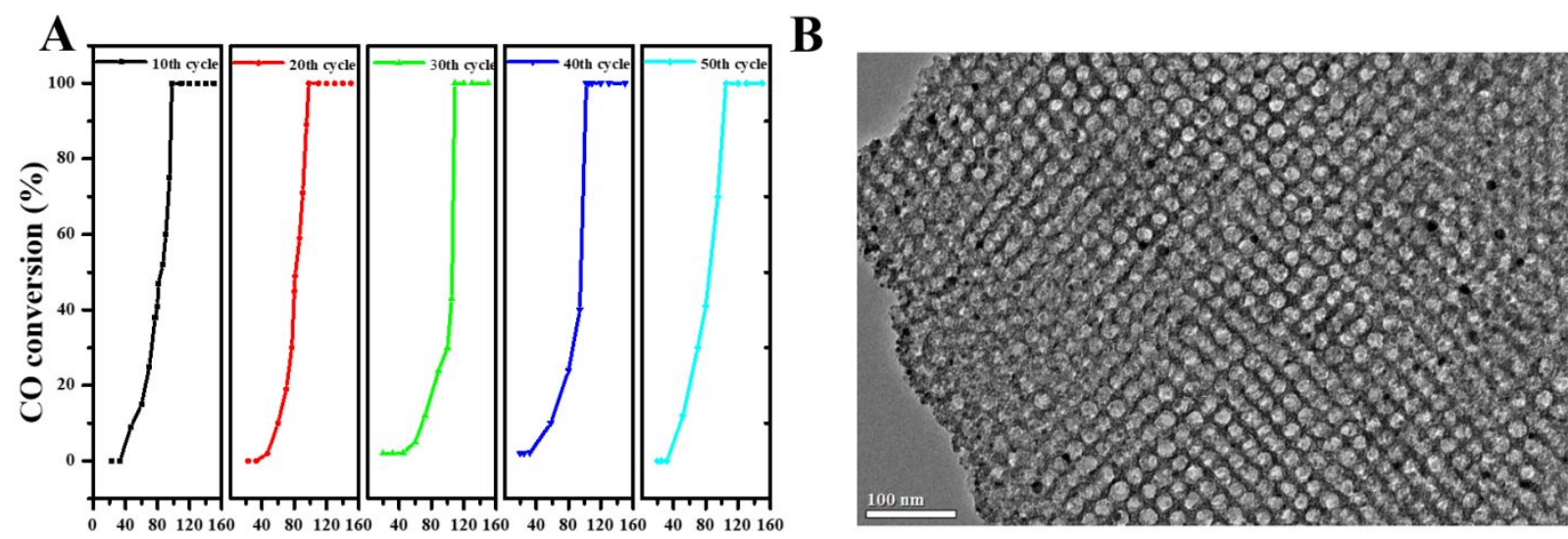

Temperature $\left({ }^{\circ} \mathrm{C}\right)$

Figure S14. (A) CO conversion from 20 to $160{ }^{\circ} \mathrm{C}$ with $1^{\text {st }}-50^{\text {th }}$ cycles by using the catalyst of $2 \mathrm{D}$ mesoporous $\mathrm{Pt} / \mathrm{Ce}_{0.8} \mathrm{Zr}_{0.2} \mathrm{O}_{2}$ nanosheets; (B) TEM image of $2 \mathrm{D}$ mesoporous $\mathrm{Pt} / \mathrm{Ce}_{0.8} \mathrm{Zr}_{0.2} \mathrm{O}_{2}$ nanosheets after the $\mathrm{CO}$ oxidation experiments. 


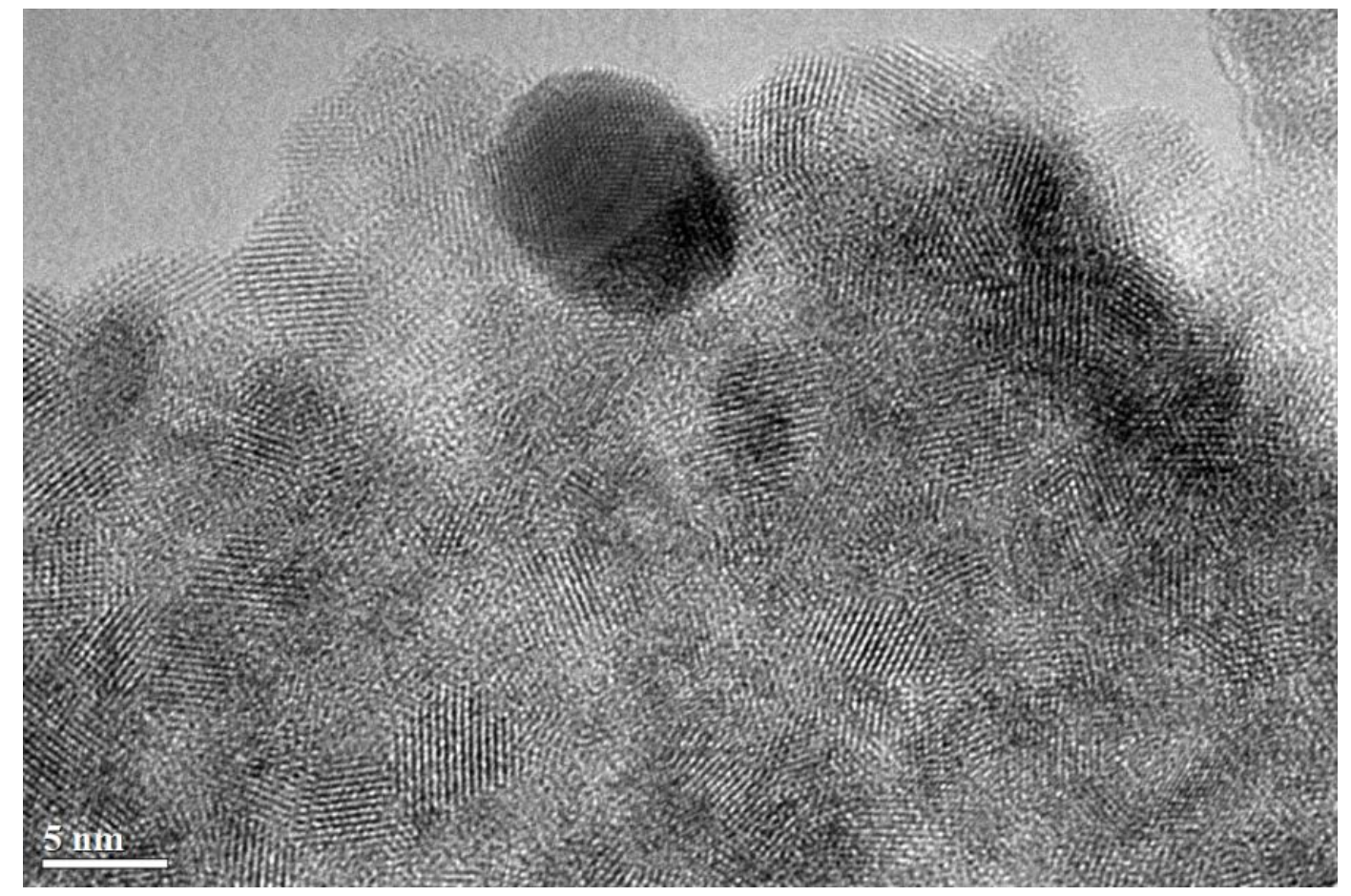

Figure S15. HRTEM image of $2 \mathrm{D}$ mesoporous $\mathrm{Pt} / \mathrm{Ce}_{0.8} \mathrm{Zr}_{0.2} \mathrm{O}_{2}$ nanosheets after the $\mathrm{CO}$ oxidation experiments.

5 

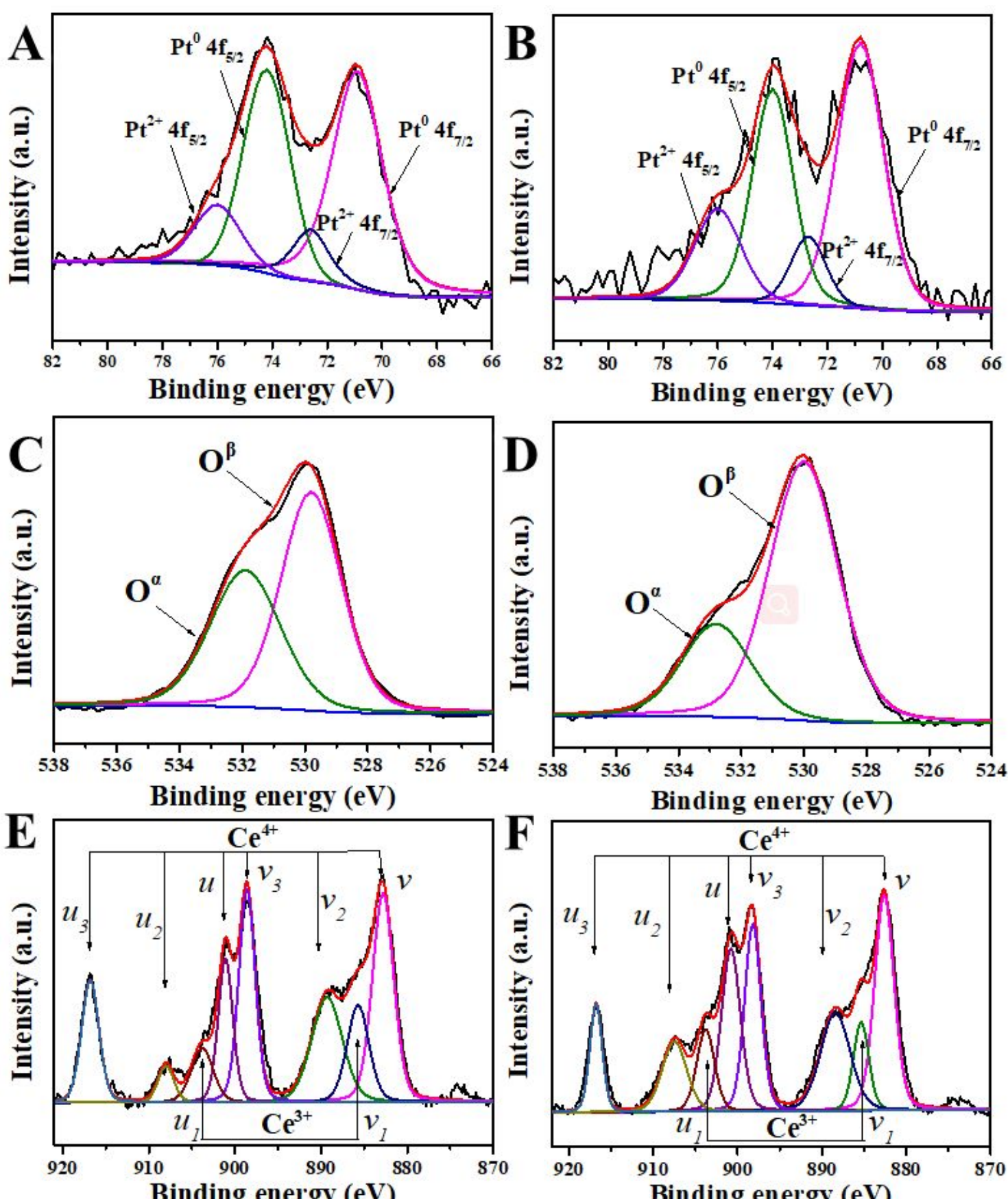

Binding energy (eV)

Figure S16. (A) Pt 4f, (C) O $1 s$ and (E) Ce $3 d$ XPS spectra of 2D mesoporous $\mathrm{Pt} / \mathrm{Ce}_{0.8} \mathrm{Zr}_{0.2} \mathrm{O}_{2}$ nanosheets; (B) Pt 4f, (D) O $1 s$ and (F) Ce $3 d$ XPS spectra of bulk mesoporous $\mathrm{Pt} / \mathrm{Ce}_{0.8} \mathrm{Zr}_{0.2} \mathrm{O}_{2}$. 

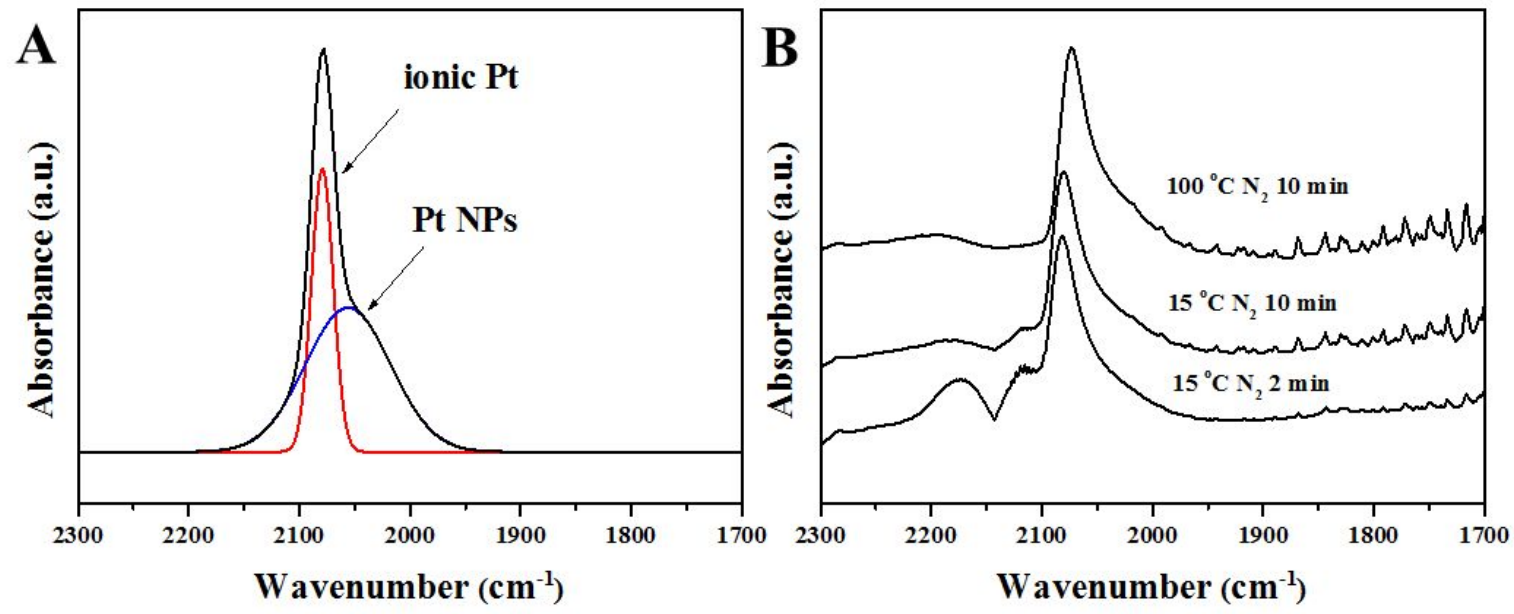

Figure S17. Selected DRIFT spectra of $\mathrm{CO}$ adsorbed on the 2D mesoporous $\mathrm{Pt} / \mathrm{Ce}_{0.8} \mathrm{Zr}_{0.2} \mathrm{O}_{2}$ nanosheets. (A) adsorption of $\mathrm{CO}$ for $30 \mathrm{~min}$; (B) desorption with flushing in $\mathrm{N}_{2}$ at different temperatures for different time. 

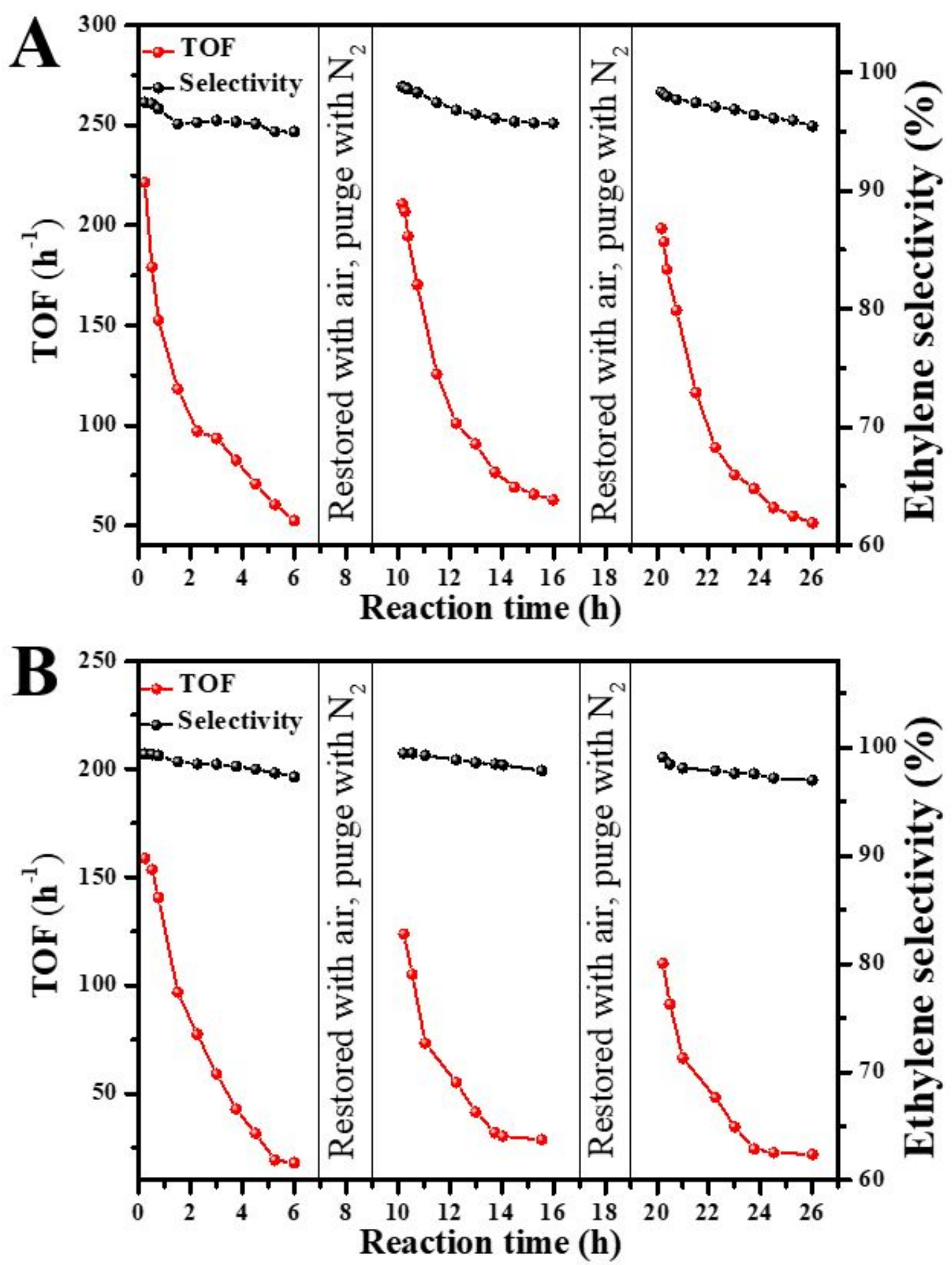

Figure S18. Turnover frequency, ethylene selectivity and regeneration test of nonoxidative dehydrogenation of ethane over (A) $2 \mathrm{D}$ mesoporous $\mathrm{Pt} / \mathrm{Ce}_{0.8} \mathrm{Zr}_{0.2} \mathrm{O}_{2}$ nanosheets; (B) 3D mesoporous $\mathrm{Pt} / \mathrm{Ce}_{0.8} \mathrm{Zr}_{0.2} \mathrm{O}_{2}$. 
To further explore the application potentials of $2 \mathrm{D}$ mesoporous $\mathrm{Pt} / \mathrm{Ce}_{0.8} \mathrm{Zr}_{0.2} \mathrm{O}_{2}$ nanosheets in other heterogeneous cataylytic reactions, the catalytic nonoxidative dehydrogenation of ethane (DHE) to ethylene was performed, which is one of the most important fundamental transformation reactions in chemical industry. DHE over these supported Pt catalysts was carried out at $650{ }^{\circ} \mathrm{C}$, and the result was shown in Figure S18 and Table S5. Clearly, all catalysts exhibited high selectivity to the target product ethylene ( $>95 \%)$, and the only by-product is methane (Table S5). The initial ethane conversion was $32.34 \%$ of $2 \mathrm{D}$ mesoporous $\mathrm{Pt} / \mathrm{Ce}_{0.8} \mathrm{Zr}_{0.2} \mathrm{O}_{2}$ nanosheets, corresponding to a $\mathrm{TOF}_{\mathrm{pt}}$ of $221.46 \mathrm{~h}^{-1}$, which was relatively higher than that of $3 \mathrm{D}$ mesoporous $\mathrm{Pt} / \mathrm{Ce}_{0.8} \mathrm{Zr}_{0.2} \mathrm{O}_{2}$ (ethane conversion of $23.19 \%$ and $\mathrm{TOF}_{\mathrm{pt}}$ of $158.73 \mathrm{~h}^{-1}$ ), indicating the much higher catalytic efficiency of 2D mesoporous $\mathrm{Pt} / \mathrm{Ce}_{0.8} \mathrm{Zr}_{0.2} \mathrm{O}_{2}$ nanosheets. In comparison with $3 \mathrm{D}$ mesoporous $\mathrm{Pt} / \mathrm{Ce}_{0.8} \mathrm{Zr}_{0.2} \mathrm{O}_{2}, \quad 2 \mathrm{D}$ mesoporous $\mathrm{Pt} / \mathrm{Ce}_{0.8} \mathrm{Zr}_{0.2} \mathrm{O}_{2}$ nanosheets possess highly accessible and exposed large number of active sites, facilitating ethane molecules to interact with the supported and in-pore confined Pt nanoparticles to perform the $\mathrm{C}-\mathrm{H}$ bond activation for nonoxidative dehydrogenation of ethane. Thanks to the unique porous nanosheets structure with rich active interfaces, the $2 \mathrm{D}$ mesoporous $\mathrm{Pt} / \mathrm{Ce}_{0.8} \mathrm{Zr}_{0.2} \mathrm{O}_{2}$ nanosheets exhibited better catalytic efficiency toward DHE as compared to other catalyst systems (Table S6).

Addtionally, the $2 \mathrm{D}$ mesoporous $\mathrm{Pt} / \mathrm{Ce}_{0.8} \mathrm{Zr}_{0.2} \mathrm{O}_{2}$ materials show excellent reuseability with high conversion of ethane $(30.78 \%)$ after regeneration at $650{ }^{\circ} \mathrm{C}$ for $2 \mathrm{~h}$ in air followed by purge with $\mathrm{N}_{2}$ for another $1 \mathrm{~h}$. The structure of $2 \mathrm{D}$ mesoporous $\mathrm{Pt} / \mathrm{Ce}_{0.8} \mathrm{Zr}_{0.2} \mathrm{O}_{2}$ nanosheets after regeneration are exmained in detail, and the results of XRD measurement, $\mathrm{N}_{2}$ sorption and TEM observation indicated that the regenerated materials are similar with the fresh 
catalyst (Figure S20 and S21). It implies that the catalyst structure is stable under harsh conditions without sintering of Pt nanoparticles. Moreover, after regeneration two times, the ethane conversion of $2 \mathrm{D}$ mesoporous $\mathrm{Pt} / \mathrm{Ce}_{0.8} \mathrm{Zr}_{0.2} \mathrm{O}_{2}$ nanosheets can maintain at about $30 \%$, demonstrating that the 2D mesoporous $\mathrm{Pt} / \mathrm{Ce}_{0.8} \mathrm{Zr}_{0.2} \mathrm{O}_{2}$ nanosheets possess the much better resuability against harsh conditions at high temperatures. Thereofre, the ultrashort-distance of mass diffusion, highly exposed active sites and synergistic effect between $2 \mathrm{D} \mathrm{Ce}_{0.8} \mathrm{Zr}_{0.2} \mathrm{O}_{2}$ matrix and Pt species, as well as the high thermal stability of $2 \mathrm{D}$ mesoporous $\mathrm{Pt} / \mathrm{Ce}_{0.8} \mathrm{Zr}_{0.2} \mathrm{O}_{2}$ nanosheets enables excellent catalytic performance with high catalytic activity, selectivity and reuseablity even in harsh conditions.

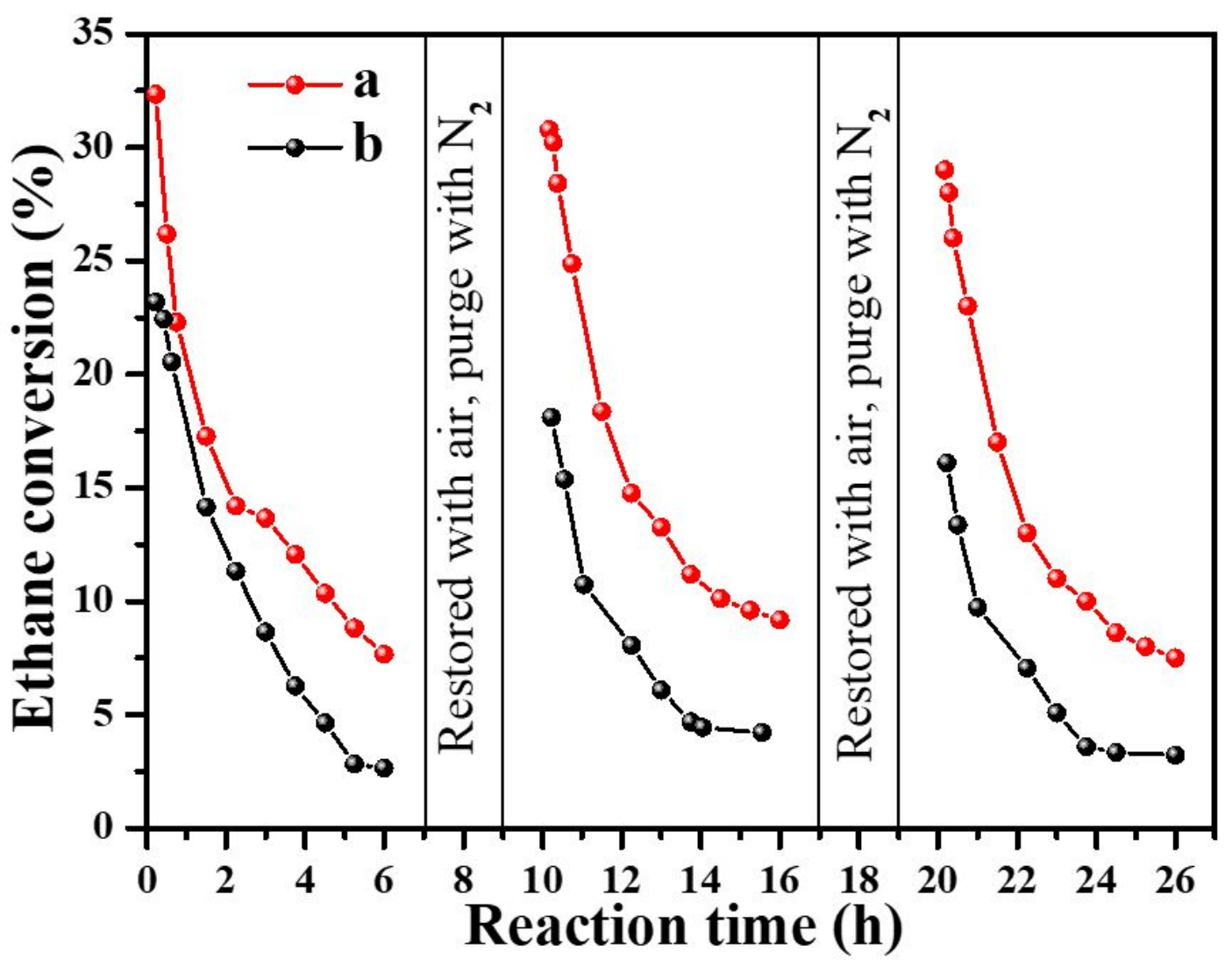

Figure S19. Regeneration test of (a) $2 \mathrm{D} \quad \mathrm{Pt} / \mathrm{Ce}_{0.8} \mathrm{Zr}_{0.2} \mathrm{O}_{2}$ nanosheets and (b) 
mesoporous $\mathrm{Pt} / \mathrm{Ce}_{0.8} \mathrm{Zr}_{0.2} \mathrm{O}_{2}$ by re-calcination.
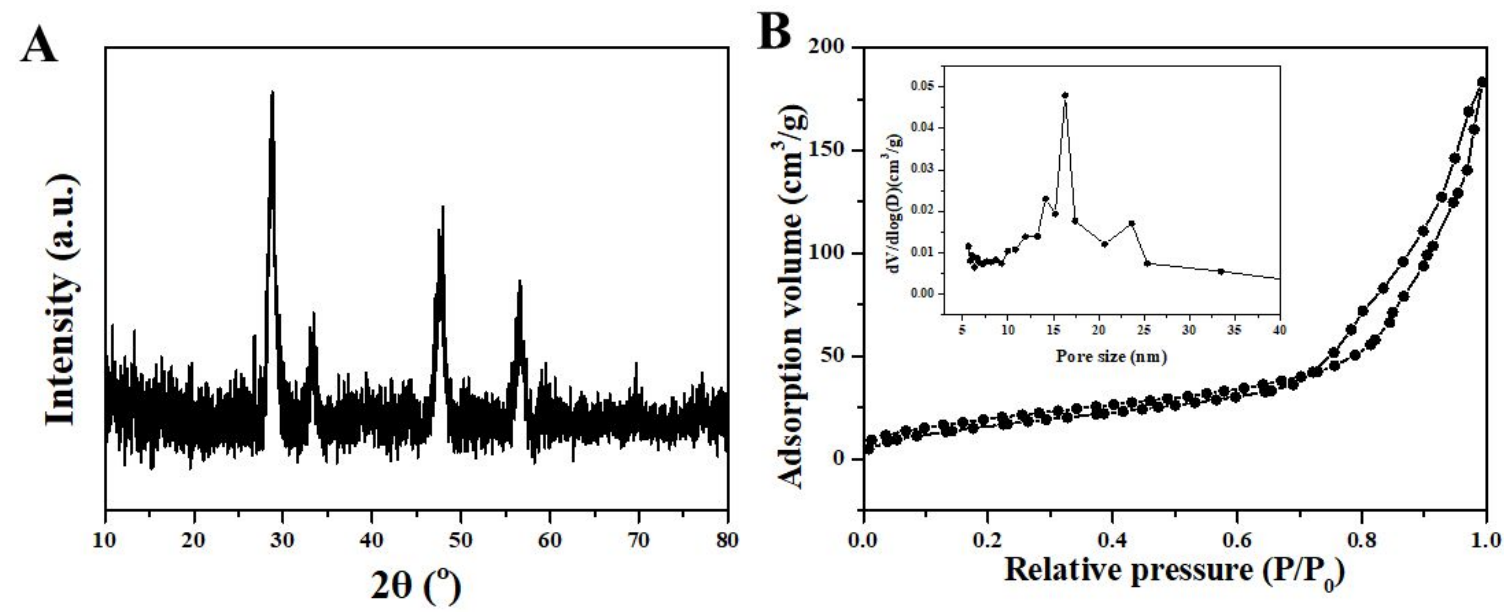

Figure S20. (A) WAXRD pattern of samples; (B) Nitrogen adsorption-desorption isotherms of samples, the inset is the pore size distribution of mesoporous $\mathrm{Pt} / \mathrm{Ce}_{0.8} \mathrm{Zr}_{0.2} \mathrm{O}_{2}$ after dehydrogenation of ethane.
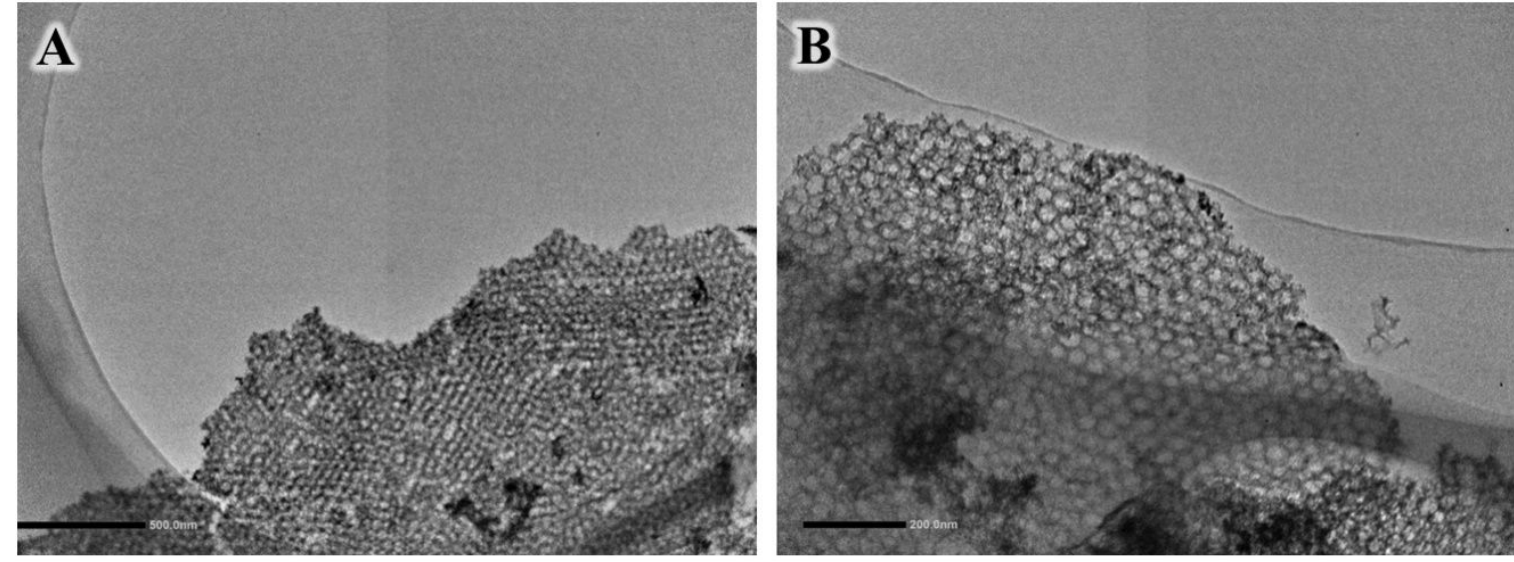

Figure S21. TEM image of $2 \mathrm{D}$ mesoporous $\mathrm{Pt} / \mathrm{Ce}_{0.8} \mathrm{Zr}_{0.2} \mathrm{O}_{2}$ nanosheets after dehydrogenation of ethane. 
Table S1. Textural properties of the $2 \mathrm{D}$ mesoporous $\mathrm{Ce}_{0.8} \mathrm{Zr}_{0.2} \mathrm{O}_{2}$ nanosheets samples by using different $\mathrm{PEO}_{\mathrm{x}}-b-\mathrm{PS}_{\mathrm{y}}$ copolymers.

\begin{tabular}{|c|c|c|c|}
\hline Sample & $\begin{array}{l}\text { Pore } \\
\text { size } \\
(\mathrm{nm})^{a}\end{array}$ & $\begin{array}{l}\text { Surface } \\
\text { Area } \\
\left(\mathrm{m}^{2} / \mathrm{g}\right)^{a}\end{array}$ & $\begin{array}{l}\text { Pore } \\
\text { Volume } \\
\left(\mathrm{cm}^{3} / \mathrm{g}\right)^{a}\end{array}$ \\
\hline $2 \mathrm{D} \mathrm{Ce}_{0.8} \mathrm{Zr}_{0.2} \mathrm{O}_{2}-\mathrm{PEO}_{117}-b-\mathrm{PS}_{130}$ & 20.5 & 110.9 & 0.216 \\
\hline $2 \mathrm{D} \mathrm{Ce}_{0.8} \mathrm{Zr}_{0.2} \mathrm{O}_{2}-\mathrm{PEO}_{47}-b-\mathrm{PS}_{169}$ & 23.6 & 106.7 & 0.204 \\
\hline $2 \mathrm{D} \mathrm{Ce}_{0.8} \mathrm{Zr}_{0.2} \mathrm{O}_{2}-\mathrm{PEO}_{117}-b-\mathrm{PS}_{182}$ & 25.1 & 105.6 & 0.192 \\
\hline $2 \mathrm{D} \mathrm{Ce}_{0.8} \mathrm{Zr}_{0.2} \mathrm{O}_{2}-\mathrm{PEO}_{117}-b-\mathrm{PS}_{220}$ & 28.7 & 98.7 & 0.185 \\
\hline 2D Pt/ $/ \mathrm{Ce}_{0.8} \mathrm{Zr}_{0.2} \mathrm{O}_{2}-\mathrm{PEO}_{117}-b-\mathrm{PS}_{130}$ & 18.9 & 109.7 & 0.198 \\
\hline $3 \mathrm{D} \mathrm{Ce} \mathrm{e}_{0.8} \mathrm{Zr}_{0.2} \mathrm{O}_{2}$ & 12.3 & 71.9 & 0.131 \\
\hline
\end{tabular}

${ }^{a}$ The data based on $\mathrm{N}_{2}$ sorption isotherm curves.

Table S2. Surface element compositions and $\mathrm{H}_{2}$ consumption of the samples. 


\begin{tabular}{|c|c|c|c|c|c|c|}
\hline & \multirow[b]{2}{*}{$\mathrm{O}^{\alpha} / \mathrm{O}^{\alpha}+\mathrm{O}^{\beta}$} & \multirow[b]{2}{*}{$\mathrm{Pt}^{0} / \mathrm{Pt}^{2+}$} & \multirow[b]{2}{*}{$\mathrm{Ce}^{3+} /\left(\mathrm{Ce}^{3+}+\mathrm{Ce}^{4+}\right)$} & \multirow{2}{*}{$\begin{array}{c}\text { temperature } \\
\left({ }^{\circ} \mathrm{C}\right)\end{array}$} & \multirow{2}{*}{$\begin{array}{l}\text { consumption } \\
(\mathrm{mmol} / \mathrm{g})^{a}\end{array}$} & \multirow{2}{*}{$\frac{\text { oxidation }}{\mathrm{T}_{100}\left({ }^{\circ} \mathrm{C}\right)^{b}}$} \\
\hline & & & & & & \\
\hline $\begin{array}{c}\mathrm{Pt} / \mathrm{Ce}_{0.8} \mathrm{Zr}_{0.2} \mathrm{O}_{2} \\
\text { nanosheets }\end{array}$ & 0.41 & $4: 1$ & 0.28 & $350 / 550$ & 1.09 & 95 \\
\hline $\begin{array}{c}\text { Mesoporous } \\
\mathrm{Pt} / \mathrm{Ce}_{0.8} \mathrm{Zr}_{0.2} \mathrm{O}_{2}\end{array}$ & 0.32 & $3.3: 1$ & 0.19 & $350 / 570$ & 0.87 & 130 \\
\hline $\begin{array}{c}\mathrm{Ce}_{0.8} \mathrm{Zr}_{0.2} \mathrm{O}_{2} \\
\text { nanosheets }\end{array}$ & 0.31 & - & 0.27 & $450 / 650$ & 0.61 & 425 \\
\hline $\begin{array}{l}\text { Mesoporous } \\
\mathrm{Ce}_{0.8} \mathrm{Zr}_{0.2} \mathrm{O}_{2}\end{array}$ & 0.27 & - & 0.21 & $450 / 650$ & 0.52 & 470 \\
\hline
\end{tabular}

${ }^{a}$ The data estimated by quantitatively analyzing the $\mathrm{H}_{2}$ TPR profiles.

${ }^{b}$ The temperature measured under the condition of $100 \%$ conversion of $\mathrm{CO}$.

Table S3. CO oxidation performance of the Pt-supported samples.

\begin{tabular}{|c|c|c|c|c|c|c|c|c|}
\hline \multirow[b]{2}{*}{ Sample } & \multicolumn{6}{|c|}{ CO conversion and apparent activation energy } & \multirow{2}{*}{$\begin{array}{c}\mathrm{Pt} w \mathrm{wt} \% \\
\mathrm{c}\end{array}$} & \multirow{2}{*}{$\begin{array}{c}\text { Space } \\
\text { velocity } \\
\mathrm{mL} /(\mathrm{g} \cdot \mathrm{h})\end{array}$} \\
\hline & $\begin{array}{l}T_{10 \%} \\
\left({ }^{\circ} \mathrm{C}\right) \\
\end{array}$ & $\begin{array}{l}T_{50 \%} \\
\left({ }^{\circ} \mathrm{C}\right) \\
\end{array}$ & $\begin{array}{l}T_{90 \%} \\
\left({ }^{\circ} \mathrm{C}\right) \\
\end{array}$ & $\begin{array}{l}T_{100 \%} \\
\left({ }^{\circ} \mathrm{C}\right)\end{array}$ & $\begin{array}{c}E \mathrm{a} \\
(\mathrm{kJ} / \mathrm{mol})^{\mathrm{a}}\end{array}$ & $\Gamma^{\mathrm{b}}$ & & \\
\hline $\begin{array}{c}\mathrm{Pt} / \mathrm{Ce}_{0.8} \mathrm{Zr}_{0.2} \mathrm{O}_{2} \\
\text { nanosheet }\end{array}$ & 47 & 80 & 90 & 95 & 50.2 & $1.3 \times 10^{7}$ & 0.91 & 12000 \\
\hline $\begin{array}{c}\text { Mesoporous } \\
\mathrm{Pt} / \mathrm{Ce}_{0.8} \mathrm{Zr}_{0.2} \mathrm{O}_{2}\end{array}$ & 106 & 135 & - & 139 & 53.2 & $2.6 \times 10^{6}$ & 0.86 & 12000 \\
\hline
\end{tabular}

${ }^{a}$ Apparent activation energy $\left(\mathrm{E}_{\mathrm{a}}\right)$ was calculated according to the Arrhenius plots. ${ }^{b}$ Pre-exponential factors $(I)$ was calculated according to the Arrhenius plots.

${ }^{c}$ The $\mathrm{Pt}$ wt $\%$ was measured by ICP.

Table S4. Comparison of CO oxidation performance of various catalysts.

\begin{tabular}{ccccc}
\hline Sample & $\begin{array}{c}T_{50} \\
\left({ }^{\circ} \mathrm{C}\right)\end{array}$ & $\begin{array}{c}T_{100} \\
\left({ }^{\circ} \mathrm{C}\right)\end{array}$ & $\begin{array}{c}\text { TOF } \\
\left(\mathrm{s}^{-1}\right)\end{array}$ & Ref. \\
\hline $\begin{array}{c}2 \mathrm{D} \mathrm{Pt} / \mathrm{Ce}_{0.8} \mathrm{Zr}_{0.2} \mathrm{O}_{2} \\
\text { nanosheet }\end{array}$ & 80 & 95 & $6.23\left(60^{\circ} \mathrm{C}\right)$ & This work \\
$\mathrm{Pt} / \mathrm{Ce}_{0.8} \mathrm{Zr}_{0.2} \mathrm{O}_{2}$ & 121 & 130 & $1.97\left(90^{\circ} \mathrm{C}\right)$ & 4
\end{tabular}




\begin{tabular}{|c|c|c|c|c|}
\hline $\mathrm{Pt}-\mathrm{CeO}_{2}$ & 155 & 240 & $\begin{array}{c}0.55 \\
\left(145^{\circ} \mathrm{C}\right)\end{array}$ & 5 \\
\hline Pt- $\mathrm{Ce}_{0.7} \mathrm{Zr}_{0.3} \mathrm{O}_{2}$ & 175 & 250 & $\begin{array}{c}0.35 \\
\left(145^{\circ} \mathrm{C}\right)\end{array}$ & 5 \\
\hline $\mathrm{Pt}-\mathrm{Ce}_{0.67} \mathrm{Zr}_{0.33} \mathrm{O}_{2}$ & 202 & 260 & $\begin{array}{c}\text { Not } \\
\text { mentioned }\end{array}$ & 6 \\
\hline Pt-Ce ${ }_{0.5} \mathrm{Zr}_{0.5} \mathrm{O}_{2}$ & 125 & 250 & $\begin{array}{c}\text { Not } \\
\text { mentioned }\end{array}$ & 7 \\
\hline 1.0Pt $/ \mathrm{Ce}_{0.33} \mathrm{Zr}_{0.67} \mathrm{O}_{2}$ & 89 & 130 & $\begin{array}{c}\text { Not } \\
\text { mentioned }\end{array}$ & 8 \\
\hline $2 \mathrm{Au} / \mathrm{Ce}_{0.5} \mathrm{Zr}_{0.5} \mathrm{O}_{2}$ & 125 & 150 & $\begin{array}{c}\text { Not } \\
\text { mentioned }\end{array}$ & 9 \\
\hline
\end{tabular}

Table S5. Reaction date in the ethane dehydrogenation.

\begin{tabular}{|c|c|c|c|c|c|}
\hline \multirow{2}{*}{ Catalysts } & \multirow{2}{*}{$\begin{array}{l}\text { Conversion } \\
(\%)^{\mathrm{a}}\end{array}$} & \multicolumn{2}{|c|}{ Selectivity $(\%)^{\mathrm{a}}$} & \multirow{2}{*}{$\begin{array}{l}\mathrm{C}_{2} \mathrm{H}_{4} \\
(\%)^{\mathrm{a}}\end{array}$} & \multirow{2}{*}{$\begin{array}{l}\text { Carbon } \\
\text { balance (\%) }\end{array}$} \\
\hline & & $\mathrm{CH}_{4}$ & $\mathrm{C}_{2} \mathrm{H}_{4}$ & & \\
\hline $\begin{array}{l}\mathrm{Pt} / \mathrm{Ce}_{0.8} \mathrm{Zr}_{0.2} \mathrm{O}_{2} \\
\text { nanosheet }\end{array}$ & $32.34(7.66)$ & $2.53(5.02)$ & $97.47(95.01)$ & $31.52(7.27)$ & 95 \\
\hline $\begin{array}{l}\text { Mesoporous } \\
\mathrm{Pt} / \mathrm{Ce}_{0.8} \mathrm{Zr}_{0.2} \mathrm{O}_{2}\end{array}$ & $23.19(2.64)$ & $0.59(2.71)$ & $99.41(97.29)$ & $23.05(2.56)$ & 96 \\
\hline $\begin{array}{l}\mathrm{Pt} / \mathrm{Ce}_{0.8} \mathrm{Zr}_{0.2} \mathrm{O}_{2} \\
\text { nanosheet-R1 }\end{array}$ & $30.78(9.17)$ & $1.24(4.31)$ & $98.76(95.69)$ & $30.39(8.77)$ & 95 \\
\hline $\begin{array}{l}\text { Mesoporous } \\
\mathrm{Pt} / \mathrm{Ce}_{0.8} \mathrm{Zr}_{0.2} \mathrm{O}_{2}-\mathrm{R} 1\end{array}$ & $18.10(4.21)$ & $0.54(5.02)$ & $99.46(97.87)$ & $18.01(4.12)$ & 96 \\
\hline $\begin{array}{l}\mathrm{Pt} / \mathrm{Ce}_{0.8} \mathrm{Zr}_{0.2} \mathrm{O}_{2} \\
\text { nanosheet-R2 }\end{array}$ & $29.67(7.50)$ & $1.64(4.55)$ & $98.36(95.45)$ & $28.53(7.15)$ & 95 \\
\hline $\begin{array}{l}\text { Mesoporous } \\
\mathrm{Pt} / \mathrm{Ce}_{0.8} \mathrm{Zr}_{0.2} \mathrm{O}_{2}-\mathrm{R} 2\end{array}$ & $16.07(3.19)$ & $0.90(3.03)$ & $99.10(96.97)$ & $15.92(3.09)$ & 96 \\
\hline
\end{tabular}

Reaction condition: $200 \mathrm{mg}$ catalyst, $650{ }^{\circ} \mathrm{C}, 3 \% \mathrm{C}_{2} \mathrm{H}_{6}$ in $\mathrm{N}_{2}$, flow rate $30 \mathrm{~mL} / \mathrm{min}$.

$\mathrm{R} 1$ represents the catalysts experience the first regeneration.

$\mathrm{R} 2$ represents the catalysts experience the second regeneration.

a The values outside and inside the brackets are obtained at $10 \mathrm{~min}$ and $6 \mathrm{~h}$, respectively. 
Table S6. Summary of the catalytic data for ethane dehydrogenation.

\begin{tabular}{|c|c|c|c|c|}
\hline Catalysts & $\begin{array}{l}\text { Reaction } \\
\text { temperature }\left({ }^{\circ} \mathrm{C}\right)\end{array}$ & Conversion (\%) & $\operatorname{TOF}\left(\mathrm{h}^{-1}\right)^{\mathrm{a}}$ & References \\
\hline $\mathrm{Pt} / \mathrm{Mg}(\mathrm{Al}) \mathrm{O}$ & 550 & $10.4(1.0)^{\mathrm{b}}$ & 226 & 10 \\
\hline $\mathrm{Fe} / \mathrm{TiO}_{2}$ & 550 & 9.7 & 63.9 & 11 \\
\hline Pd-In-0.2 & 600 & - & $45.4(15.1)^{c}$ & 12 \\
\hline Pd-In-0.8 & 600 & - & $112(51.8)^{\mathrm{c}}$ & 12 \\
\hline $\mathrm{Pd}$ & 600 & - & $50.8(5.1)^{\mathrm{c}}$ & 12 \\
\hline $\mathrm{Au} / \mathrm{SiTi}-20$ & 650 & $15.8(11.7)^{\mathrm{d}}$ & $37.5(27.8)^{d}$ & 13 \\
\hline $\mathrm{Au} / \mathrm{CeO}_{2}$ & 650 & $13.7(2.6)^{\mathrm{d}}$ & $32.5(6.2)^{\mathrm{d}}$ & 14 \\
\hline $\begin{array}{c}\mathrm{Pt} / \mathrm{Ce}_{0.8} \mathrm{Zr}_{0.2} \mathrm{O}_{2} \\
\text { nanosheet }\end{array}$ & 650 & $32.34(7.66)^{d}$ & $221(52.4)^{d}$ & Present work \\
\hline
\end{tabular}

TOF was calculated based on the following equation:

$$
\operatorname{TOF}\left(h^{-1}\right)=X_{\text {ethane }} F_{\text {ethane }} \frac{M}{m X D_{P t}}
$$

The $X_{\text {ethane }}$ represented the ethane conversion at certain temperature, the $F_{\text {ethane }}$ represented the ethane flow rate in unit of $\mathrm{mol} / \mathrm{h}, m$ represented the catalyst amount, $X$ represented the loading amount of active species, $D$ represented the dispersion of the active species.

$\mathrm{b}$ The values inside the brackets are obtained at $2 \mathrm{~h}$.

${ }^{c}$ The values inside the brackets are obtained at $3 \mathrm{~h}$.

${ }^{\mathrm{d}}$ The values inside the brackets are obtained at $6 \mathrm{~h}$.

\section{References}

[1] Arandiyan, H.; Dai, H.; Ji, K.; Sun, H.; Li, J. Pt Nanoparticles Embedded in Colloidal Crystal Template Derived 3D Ordered Macroporous $\mathrm{Ce}_{0.6} \mathrm{Zr}_{0.3} \mathrm{Y}_{0.1} \mathrm{O}_{2}$ : Highly Efficient Catalysts for Methane Combustion. ACS Catal. 2015, 5, 1781-1793.

[2] Ricote, S.; Jacobs, G.; Milling, M.; Ji, Y.; Patterson, P. M.; Davis, B. H. Low temperature water-gas shift: Characterization and testing of binary mixed oxides of ceria and zirconia promoted with Pt. Appl. Catal., A 2006, 303, 35-47. 
[3] Liu, L.; Zhou, F.; Wang, L.; Qi, X.; Shi, F.; Deng, Y. Low-temperature CO oxidation over supported Pt, Pd catalysts: Particular role of FeOx support for oxygen supply during reactions. J. Catal. 2010, 274, 1-10.

[4] Yang, X.; Cheng, X.; Ma, J.; Zou, Y.; Luo, W.; Deng, Y. Large-Pore Mesoporous $\mathrm{CeO}_{2}-\mathrm{ZrO}_{2}$ Solid Solutions with In-Pore Confined Pt Nanoparticles for Enhanced CO Oxidation. Small 2019, 15, 1903058.

[5] Shen, M.; Lv, L.; Wang, J.; Zhu, J.; Huang, Y.; Wang, J. Study of Pt dispersion on Ce based supports and the influence on the $\mathrm{CO}$ oxidation reaction. Chem. Eng. J. 2014, $255,40-48$.

[6] Wu, X.; Fan, J.; Ran, R.; Weng, D. Effect of preparation methods on the structure and redox behavior of platinum-ceria-zirconia catalysts. Chem. Eng. J. 2005, 109, 133-139.

[7] Yuan, Q.; Liu, Q.; Song, W. G.; Feng, W.; Pu, W. L.; Sun, L. D.; Zhang, Y. W.; Yan, C. H. Ordered Mesoporous $\mathrm{Ce}_{1-x} \mathrm{Zr}_{x} \mathrm{O}_{2}$ Solid Solutions with Crystalline Walls. $J$. Am. Chem. Soc. 2007, 129, 6698-6699.

[8] Kamiuchi, N.; Haneda, M.; Ozawa, M. CO oxidation over Pt/Ce-Zr oxide catalysts with low content of platinum and cerium components. Catal. Today 2013, $201,79-84$.

[9] Izabela, D.; Ireneusz, K.; Jacek, M. Factors influencing structure and catalytic activity of $\mathrm{Au} / \mathrm{Ce}_{1-x} \mathrm{Zr}_{x} \mathrm{O}_{2}$ catalysts in $\mathrm{CO}$ oxidation. Appl. Catal., B 2009, 88, 83-97. [10] Zhang, Q.; Zhang, K.; Zhang, S.; Liu, Q.; Chen, L.; Li, X.; Wang, C.; Ma, L. $\mathrm{Ga}^{3+}$-stabilized $\mathrm{Pt}$ in $\mathrm{PtSn}-\mathrm{Mg}(\mathrm{Ga})(\mathrm{Al}) \mathrm{O}$ catalyst for promoting ethane dehydrogenation. J. Catal. 2018, 368, 79-88.

[11] Jeong, M.; Sun, J.; Han, G.; Lee, D.; Bae, J. Successive reduction-oxidation activity of $\mathrm{FeO}_{\mathrm{x}} / \mathrm{TiO}_{2}$ for dehydrogenation of ethane and subsequent $\mathrm{CO}_{2}$ activation. Appl. Catal., B 2020, 270, 118887.

[12] Wu, Z.; Wegener, E.; Tseng, H.; Gallagher, J,; Harris, J.; Diaz, R.; Ren, Y.; Ribeiro, F.; Miller, J. Pd-In intermetallic alloy nanoparticles: highly selective ethane dehydrogenation catalysts. Catal. Sci. Technol. 2016, 6, 6965-6976. 
[13] Xie, Q.; Lei, T.; Miao, C.; Hua, W.; Yue, Y.; Gao, Z. Au/TiO 2 for Ethane Dehydrogenation: Effect of Silica Doping. Catal. Lett. 2020, 150, 2013-2020.

[14] Lei, T.; Miao, C.; Hua, W.; Yue, Y.; Gao, Z. Oxidative Dehydrogenation of Ethane with $\mathrm{CO}_{2}$ over $\mathrm{Au} / \mathrm{CeO}_{2}$ Nanorod Catalysts. Catal. Lett. 2018, 148, $1634-1642$. 